\title{
Interpretação crítico-fenomenológica da noção de valor na Teoria Tridimensional do Direito de Miguel Reale
}

\author{
Ricardo Afonso-Rocha \\ Graduando em Direito pela Universidade Estadual de Santa Cruz (UESC). Pesquisador \\ bolsista do grupo de pesquisa Jurisdição Constitucional, Hermenêutica e Democracia \\ (JHCD), fomentado pelo programa de pesquisa da UESC. E-mail: rocha.r174@gmail.com

\section{lago dos Santos Moura-Melo} \\ Graduando em Direito pela Universidade Estadual de Santa Cruz (UESC). Pesquisador \\ bolsista do grupo de pesquisa Jurisdição Constitucional, Hermenêutica e Democracia \\ (JHCD), fomentado pelo programa de pesquisa da UESC. E-mail: \\ iagommsantos@hotmail.com
}

\section{Carlos Roberto Guimarães}

Doutorando em Filosofia pela Universidade Federal do Rio de Janeiro (UFRJ). Mestre em Filosofia pela UFRJ. Graduado em Filosofia pela Universidade Federal de Ouro Preto (UFOP).

\section{Resumo}

O presente estudo se consubstancia numa interpretação ao modo crítico da noção de valor presente no pensamento de Miguel Reale em sua Teoria Tridimensional do Direito, com base nos aportes teóricos e metodológicos dos estudos da fenomenologia hermenêutica, desenvolvida por Martin Heidegger em Ser e Tempo (Sein und Zeit). Busca analisar se há consistência teorética na síntese proposta por Reale entre personalismo e historicismo axiológico, a partir da qual fundamenta o que denomina "invariantes axiológicas". Para tanto, apresenta a noção de valor realena enquanto síntese que, a priori, possibilita a compreensão do ente pela correlação ontognoseológica entre sujeito-objeto e que se constitui como cultura pela objetivação da intencionalidade da consciência nos processos históricos. Pretende, assim, sugerir que, ao fazer este movimento, Reale não supera as tradições kantiana e husserlena, como afirma fazer, além de, também, não se manter estritamente fiel a tais tradições filosóficas, bem como que a síntese por ele querida é forçosa.

\section{Revista Publicum}

Rio de Janeiro, v.2, n. 2, 2016, p. 169-204

http://www.e-publicacoes.uerj.br/index.php/publicum

DOI: 10.12957/publicum.2016.22557 


\title{
Palavras-chave
}

Fenomenologia; Axiologia; Ontognoseologia; Teoria Tridimensional do Direito; Invariantes Axiológicas.

\section{Critical Appreciation of the value's notion in Miguel Reale's Three Dimensional Theory of Law}

\begin{abstract}
The present essay appreciates critically the notion of the present value in the thought of Miguel Reale wich has been extracted of your Three-Dimensional Theory of Law (1994). Seeks to analyze, based on theoretical and methodological contributions of the studies of phenomenology hermeneutic developped by Martin Heidegger in your work Being and Time (Sein und Zeit) from 1929, Reale's proposal of synthesis between personalism and historicism, in order to realize if there is theorical consistence in the synthesis that the paulista mester intends between the doctrines husserlian and kantian, from which strengthen what is called "axiological invariants". Therefore, a priori it shows his notion of value as synthesis, which enables the comprehension of the entity by the correlation ontognoseologic between subject-object, that is formed as culture by the objectification of the conciousness' intentionality on the historical processes. Thereby, he intends to suggest that by doing this movement, Reale does not overcomes both, kantian ah husserlian, traditions like he affirms, besides, he also does not mantains strictly loyal to these philosophical traditions.
\end{abstract}

\section{Keywords}

Phenomenology; Axiology; Ontognosiology; Three-Dimensional Theory of Law; Axiological Invariants.

\section{Sumário}

Introdução; 2 Da Teoria Tridimensional do Direito; 2.1 Dos reducionismos teóricos às tricotomias abstratas, 2.2 Do tridimensionalismo Dinâmico; 3 A dialética da complementaridade e o valor em Miguel Reale; 4 Entre Kant e Husserl: interpretação críticofenomenológica da noção de valor realeana e os limites de sua pretensão sintetizante; 4.1 Immanuel Kant: o despertar do sono dogmático e a busca de uma metafísica científica; 4.2 Husserl: intencionalidade da consciência e fenomenologia das essências; 4.3 Dos limites da pretensão sintetizante; Considerações Finais; Referências.

\section{Introdução}

Miguel Reale, em seu tridimensionalismo, ao propor que o Direito é uma integração normativa de fatos segundo valores, e fundamentá-la no que chama dialética da complementaridade, sustenta um personalismo axiológico ou um jusnaturalismo personalista. A seu ver, este modo de pensar se conformaria com sua perspectiva culturalhistoricista e, dessa forma, apesar de admitir o sujeito histórico, sustenta uma noção de valor que figura como síntese a priori no plano ontognoseológico; admitindo valores 
transcendentais e tendo a pessoa como valor-fonte em que se fundamenta toda a dimensão axiológica do fenômeno jurídico.

A partir da síntese que pretende entre o historicismo e personalismo axiológico, quer o autor conferir à noção de dialética uma dimensão ampliativa, de modo a inseri-la na experiência jurídica com base no Lebenswelt (ou mundo da vida) pensado por Husserl ${ }^{1}$.

O objetivo principal deste artigo será, assim, analisar a consistência teórica na síntese que Reale pretende entre as doutrinas husserleana e kantiana, a partir das quais fundamenta o que denomina "invariantes axiológicas". Dessa forma, parece que seremos levados a sugerir que o autor não supera as matrizes kantiana e husserlena, como afirma superar, além de, também, não se manter estritamente fiel a tais tradições filosóficas.

A relevância teórica do tema decorre do imperativo de compreender a noção de valor desenvolvida pelo tridimensionalismo jurídico, nos moldes propostos por Miguel Reale, bem como da necessidade de demarcar os seus limites. Acreditamos que por meio desse movimento crítico, desocultar-se-á a possibilidade de abrir a consciência jurídica à necessidade constante de rever suas bases teoréticas, de modo a promover uma revisão de seu projeto prévio compreensivo, expressão de Hans Georg-Gadamer², a partir de uma leitura sempre atualizadora de seus fundamentos, afastando-se do que foi denominado, com muita razão, por Warat, de senso comum teórico ${ }^{3}$. Se utilizarmos uma linguagem heideggeriana, é necessário projetar, no Direito, o claro que emana de sua compreensibilidade, a partir da abertura que somos para o que ele mesmo é.

A relevância prática e pertinência social do tema residem na imprescindibilidade de visualizar as consequências epistemológicas, metodológicas e sociais resultantes do desvelamento das limitações do tridimensionalismo jurídico de Reale, bem como da necessidade de perceber as influências de sua teoria no modo de pensar o Direito atual. Este trabalho visa dar a sua contribuição para ampliar e difundir a discussão junto à comunidade de intérpretes, seres falantes, imersos na tradição da Academia, acerca do fenômeno jurídico.

Ante o exposto, o voltar-se sobre o morto é sempre um movimento fundamental para um projeto. É imperiosa a necessidade de reformular perguntas antigas, de rever questões aparentemente ultrapassadas, e de des-construir a partir da história que somos e de que dispomos. Portanto, parece-nos adequada a utilização, em sentido epistemológico, da atitude fenomenológico-hermenêutica: atitude fenomenológica - parte

${ }^{1}$ A noção de Lebenswelt foi melhor desenvolvida por Husserl, em seu livro póstumo Crise das ciências europeias e a fenomenologia transcendental.

2GADAMER, Hans-Georg. Verdade e método I. 5. Ed. Petrópolis: Vozes, 2003.

${ }^{3}$ WARAT, Luis Alberto. Manifesto do surrealismo jurídico. São Paulo: Acadêmica, 1988.

Revista Publicum

Rio de Janeiro, v.2, n. 2, 2016, p. 169-204

http://www.e-publicacoes.uerj.br/index.php/publicum

DOI: 10.12957/publicum.2016.22557 
da perspectiva de que o ser humano não é objeto e suas atividades não são meras reações. O homem é visto como atribuidor de significados históricos; o mundo e a realidade não são objetivos exteriores ao homem, mas socialmente construídos e recebem um significado a partir do homem; atitude hermenêutica - a experiência vivida é em si mesma um processo interpretativo-compreensivo. Dessa forma, o fenômeno não é desvelado em sua totalidade, porém, aprendido na complexidade como um construído da intencionalidade de quem se predispõe a conhecer no desentranhamento de uma de suas possibilidades ${ }^{4}$.

Em sentido estrito, a abordagem metodológica é o anarquismo epistemológico (ou pluralismo metodológico), de Paul Feyerabend ${ }^{5}$, vez que a apreensão da complexidade do fenômeno não é estática, mas, encontra-se em construção, o que invalida a possibilidade da utilização de apenas um único método como possibilidade final, atitude tradicional das pretensões cientificistas de Direito que se orientam como que roubado tivessem o fogo de Prometeu.

A orientação filosófica básica para conduzir essa investigação é a pesquisa crítica, nos moldes crítico-fenomenológicos, que deverá se nortear pela busca ao fenômeno, na esperança do privilegiado encontro, e isto parece ser possível por meio do reconhecimento despretensioso de que é preciso saber que estamos a abrir trilhas (Wege) em uma floresta inexplorada, não se tendo a certeza aonde chegaremos. $\mathrm{O}$ trilhar a floresta é uma das possibilidades do encontro da clareira. Quem abre trilhas, vivencia e se percebe na floresta. Quem abre trilhas possibilita o encontro privilegiado. Quanto à técnica empregada utilizar-se-á da pesquisa bibliográfica e documental na consulta da literatura ${ }^{6}$.

\section{Da Teoria Tridimensional do Direito}

A doutrina de um pensador é o que ficou não dito no seu dizer ${ }^{7}$.

Martin Heidegger.

${ }^{4}$ STEIN, Ernildo. Compreensão e finitude: estrutura e movimento da interrogação heideggeriana. ljuí, RS: UNIJUÍ, 2001.

${ }^{5}$ FEYERABEND, Paul. Contra o método. [S.I.] Relógio D'Água; Ciência, 2007.

${ }^{6}$ BITTAR, Eduardo. Metodologia da pesquisa jurídica: teoria e prática da monografia para os cursos de direito. 4. ed. São Paulo: Saraiva, 2005

${ }^{7}$ HEIDEGGER, Martin. Ensaios e conferências. 8. ed. Petrópolis: Vozes; Bragança Paulista: Editora Universitária São Francisco, 2012.

Revista Publicum

Rio de Janeiro, v.2, n. 2, 2016, p. 169-204

http://www.e-publicacoes.uerj.br/index.php/publicum

DOI: 10.12957/publicum.2016.22557 
Reale pretende, com seu tridimensionalismo, ultrapassar teorias monistas de compreensão do Direito, o normativismo, o sociologismo e o moralismo, bem como as perspectivas tricotômicas que buscam relacionar essas dimensões abstratamente. Façamos uma leitura panorâmica e breve a respeito de tais, que nos é, inclusive, fornecida pelo referido autor.

\subsection{Dos Reducionismos Teóricos às tricotomias abstratas}

O normativismo tentou explicar o Direito enquanto sistema de normas ou de regras. Desdobrou-se em variadas vertentes, distribuídas, por exemplo e sucintamente, entre a Escola Exegética - para a qual o Direito se revelava unicamente pelas leis; a Escola Analítica - que reduzia o Direito a um corpo de regras consuetudinárias, as quais ao intérprete incumbiria explicitar; o Pandectismo - que definia o Direito como corpo de regras modelado pelo Direito Romano, e o Normativismo Lógico - que tem como grande expoente Hans Kelsen e sua Teoria Pura do Direito, o qual visava preservar o Direito de uma confusão epistemológica ${ }^{8}$, de modo a afastá-lo de outros sistemas como a Ética, a Moral, a Política, a Economia, a Religião, etc. ${ }^{9}$.

O sociologismo jurídico, a seu turno, centrou o Direito na realidade social. Concebeu, assim, o Direito, exclusivamente, em seu aspecto fático. Desse modo, o Direito passou a ser visualizado como mero componente dos fenômenos sociais, passível de ser apreendido conforme nexos de causalidade não diversos dos que ordenam os fatos do mundo físico. Neste movimento se entrecruzaram doutrinas, em um abrir de perspectivas diversas: a Jurisprudência dos interesses de Max Rümelin e Philip Heck; o realismo jurídico de Léon Duguit; o sociologismo jurídico restrito, de Ehrlich, Kantorowicz, Pound e Horvath; a teoria do fato normativo de Petrasisky; são alguns dos exemplos das diversas doutrinas que são reunidas sob a rubrica de sociologismo jurídico. No Brasil, essa orientação tem entre seus representantes notáveis Tobias Barreto, Sílvio Romero, Pedro Lessa, João Arruda e Pontes

\footnotetext{
${ }^{8} \mathrm{O}$ pensamento normativista lógico Hans Kelsen, como acentua Warat, requer a libertação do direito de todos elementos estranhos; a ciência jurídica deve tão somente buscar responder o que é o direito e como é, e não tentar justificá-lo ou transformá-lo. WARAT, Luiz Roberto. A pureza do poder: uma análise crítica da teoria jurídica. Florianópolis: Ed. Da UFSC, 1983.

${ }^{9}$ Como destaca Reale, "[...] foi só em 1940 que, na realidade, pensei que o Direito não pode ser concebido à maneira de Kelsen, como uma simples norma. Então, tive a ousadia [completa Reale] de me contrapor ao jurista do nosso século, que é sem dúvida Hans Kelsen, a tal ponto que costumo dizer que ele representa o meridiano de Greenwich da Jurisprudência". REALE, Miguel. Teoria tridimensional do direito. 5. ed. rev. e reestruturada. São Paulo: Saraiva, 1994, p. 118.
} 
de Miranda, para quem "o Direito pressupõe no jurista o sociólogo que fundamentalmente deve ser" 10 .

Por sua vez, o moralismo jurídico subordinou o Direito, rigorosamente, a valores morais, de maneira a eleger a dimensão axiológica como prisma sob o qual este deve ser considerado, sem, no entanto, se confundir, ou buscando não se confundir, com o jusnaturalismo. Essa forma de conceber o Direito, inclusive, surgiu da preocupação com a validez das normas jurídicas em razão do seu conteúdo, de modo a afigurar como uma reação à querela entre sociologistas e normativistas - àqueles destacando o primado da dimensão fático-causal; esses últimos sustentando a prevalência da dimensão lógiconormativa. São expoentes dessa concepção moralista Georges Ripert, Giovanni Gentile, Julius Binder e Viktor Cathrein. No Brasil destacam-se nomes como João Mendes Jr., Vicente Ráo, Alexandre Correia e José Pedro Galvão De Souza.

Nessa esteira, uma vez feita a apresentação sucinta dos monismos que representam a antítese principal ao modo de pensar tricotômico, destacaremos as principais correntes tricotômicas do Direito, a partir das quais emerge reativamente a doutrina trivalente de Miguel Reale, de modo a percebermos em que medida sua teoria de tais se aproxima ou se afasta.

Pensar o Direito em três dimensões implica considerar a sua existência a partir de uma realidade trivalente. Ocorre, entretanto, que várias e distintas foram as teorias que o conceberam numa perspectiva tridimensional, no sentido mais amplo que se pode reconhecer a essa palavra. Reale (1992) ${ }^{11}$ as distingue entre tricotomias abstratas (ou amplas) e concretas (ou específicas). Assim, antes de chegar à delimitação do corpus sobre o qual recai a interpretação crítico-fenomenológica aqui experenciada, qual seja a noção de valor realeana, é elementar trilhar os caminhos que se cruzaram para que se propusesse um tridimensionalismo específico, na acepção que empresta Reale a este termo, já que são múltiplas as teorias que põem em destaque o caráter 'tridimensional' da experiência jurídica, nela discriminando três elementos, dimensões, fatores ou momentos, indicados, usualmente, como fato, valor e norma.

O próprio Reale nos apresenta um panorama das múltiplas tricotomias genéricas ou abstratas que o antecederam. Segundo o autor, há jusfilósofos que não admitem haver conciliação entre os pontos de vista teóricos elaborados pela sociologia, pela ciência ou pela filosofia do direito, cada uma delas constituindo um campo insuscetível de correlação, salvo

${ }^{10}$ MIRANDA, Pontes De. Sistema de Ciência Positiva do Direito. 2a ed. Rio de Janeiro: Editor Borsoi, 1972. Tomo I, p. 227.

${ }^{11}$ REALE, Miguel. 0 direito como experiência: introdução à epistemologia jurídica. 2. ed. São Paulo: Saraiva, 1992. 
no plano da ação prática ou da praxis. É nesse sentido que se desenrola o pensamento de Gustav Radbruch - tridimensionalismo que Reale denomina genérico antinômico. Bem como há alguns autores, como Emil Lask, para quem a tridimensionalidade é genérica por apresentar, ainda que implicitamente, a necessidade de uma compenetração intrasistemática e dinâmica dos três elementos.

Assim, segundo Reale ${ }^{12}$, se credita a Emil Lask e Gustav Radbruch, na Alemanha, os primeiros lumes do modo trino de conceber o Direito, os quais desenvolveram sua doutrina a partir da tensão entre o jusnaturalismo e o positivismo. Munidos dos pressupostos kantianos e aplicando os ensinamentos de Windelband e Rickert no campo do Direito, recorreram tais autores ao mundo da cultura, ou da história, - plano do ser referido ao dever ser - como elemento de ligação entre os valores ideais - plano do dever ser -, e os dados da experiência jurídica - plano do ser. Na Itália, ainda segundo Reale, Icilio Vanni e Giorgio Del Vecchio teriam se ocupado do tema ainda no bojo da jusfilosofia, gnoseologia, deontologia e fenomenologia ${ }^{13}$. Em solo francês, a seu turno, Paul Rouber teria sido o precursor da análise tricotômica - segurança jurídica, justiça e progresso social como fins que orientam o ordenamento jurídico ${ }^{14}$. Nos países anglo-americanos, Reale ${ }^{15}$ assevera que a abertura do naturalismo a um complexo de outras influências determinou a progressiva convergência das análises no sentido de uma composição pragmática, e destaca Pound, Julius Stone, Cairns e Friedmann como referenciais de concepções expressamente tricotômicas e genéricas.

Reale prossegue o panorama e notícia que considera a concepção normativista de

Hans Kelsen como sendo também tricotômica, para ele, uma tridimensionalidade

12 REALE, Miguel. Teoria tridimensional do direito. 5. ed. rev. e reestruturada. São Paulo: Saraiva, 1994, p. 24.

${ }^{13}$ Impende chamar atenção para as doutrinas posteriormente desenvolvidas na Itália, que assistiram os desenvolvimentos últimos do tridimensionalismo (teorias específicas), muito bem representadas pelos italianos Giuseppe Lumia (para quem era elementar que a experiência jurídica fosse considerada em seu aspecto integral, na multiplicidade de seus aspectos, já que tanto o filósofo quanto o jurista estariam imersos numa mesma realidade, considerada a partir de pontos de vista distintos) e Dino Pasinio, o qual "[...] distingue na realidade jurídica um momento condicionante ou situacional (o fato), um momento normativo ou estrutural (a norma) e um momento teleológico ou funcional (o valor)". Ibid., p. 34.

${ }^{14}$ No entanto, Rouber, como afirma Reale, reconhece que "[...] essa decomposição do direito é esquemática, pois a vida social jamais se inspira exclusivamente numa dessas tendências: ao contrário, elas se misturam na cena jurídica, sendo necessário determinar os seus domínios distintos de investigação" Ibid., p. 34. Dos estudos de Roubier, desenvolvem-se as doutrinas de Francis Lamand e de Michel Virally. Aquele propõe ainda o tempo como sendo uma quarta dimensão para o direito, visto que "as três dimensões - fato, valor e norma - não reconstituem a unidade do jus no tempo". REALE, Miguel. Teoria tridimensional do direito. 5. ed. rev. e reestruturada. São Paulo: Saraiva, 1994, p. 34.

${ }^{15}$ Ibid., p. 34. 
metodológico-negativa ${ }^{16}$. Sob esta ótica, Hans Kelsen desenvolvera em seu sistema a Ciência de Direito, como estudo lógico-sistemático de normas, com caráter puramente jurídico, enquanto à Teoria da Justiça e à Sociologia do Direito caberia a metajuridicidade ${ }^{17}$. Daí a denominação tridimensionalidade metodológico-negativa, já que, a partir de sua pretensão de preservar a pureza epistemológico-metodológica do Direito enquanto ciência estariam excluídos os demais domínios do conhecimento. No entanto, se considerado abstratamente o Direito, teriam lugar as incursões no domínio dos fatos e dos valores.

$\mathrm{Na}$ cultura Ibérica, afirma, podem-se assinalar muitas doutrinas tricotômicas representadas, por exemplo, pelas obras de L. Legaz y Lacambra - de influência kelseniana e da Filosofia dos Valores de Scheler e Hartmann; E. Garcia Máynez - que concebe cada uma as dimensões do Direito não como facetas de uma mesma realidade, mas como objetos distintos; Carlos Cóssio - precursor da Teoria Egológica do Direito, que, segundo Reale, traduz também uma tricotomia abstrata, já que em sua concepção do Direito como conduta em interferência subjetiva, confere à teoria lógico-kelseniana aspectos fáticos e axiológicos; Luís Recaséns Siches - que desenvolve, inicialmente, um tridimensionalismo perspectivista, como caracteriza Reale, mas que, mais tarde, rende-se ao especifismo realeano ${ }^{18}$.

Não serve à nossa trilha adentrar ao mérito das concepções abstrativistas acima qualificadas, cada uma delas renderia um estudo em apartado. Assim, contentemo-nos com as críticas de Reale a este modo de pensar. Destaca o autor, em suma síntese, que tais concepções têm como lugar comum o isolamento dos elementos componentes do fenômeno jurídico, mantendo-os em apartado para efeitos de estudo, em que caberia ao intérprete, in fine, promover uma síntese entre os três pontos de vista, a partir dos resultados obtidos de seu estudo em separado.

Desse modo, para a construção das bases teóricas do especifismo realeano, ou tridimensionalismo dinâmico, não só era necessário superar as perspectivas precárias que condensavam o fenômeno jurídico num só aspecto, a saber: o normativismo, o sociologismo e o moralismo; mas também ir além de um tratamento abstrato dos momentos do Direito. Adentremos, a seguir, na proposta trina do fenômeno jurídico que Reale desenvolve.

16 Ibid., p. 36.

${ }^{17}$ REALE, Miguel. Fundamentos da concepção tridimensional do direito. Revista da Faculdade de Direito, Universidade de São Paulo 56.2 (1961): 66-87.

18Também são correntes tricotômicas presentes na cultura ibérica as de Werner Goldschmidt, Jorge I. Hubner Gallo. Em outras áreas culturais, tem-se o exemplo das doutrinas de Barna Horvath, de Jerzy Wróblewski. 


\subsection{Do Tridimensionalismo Dinâmico}

A concepção trina de Reale apresenta, como seu projeto, a correlação dialética e complementar entre os três planos do Direito, de modo a uni-los numa unidade integrante. Este será o diferencial da abordagem de Reale com relação às concepções setorizadas e abstratas do Direito: a forma como a tensão dialética entre os três momentos do Direito pode atuar para que o fenômeno jurídico se revele tal como ele mesmo é. A essa forma de enxergar a relação de imbricação existente entre fato, valor e norma, enquanto correlação compreendida no ser mesmo do Direito, Reale denomina perspectiva ontognoseológica ${ }^{19}$. Desse modo, a vida do Direito seria, em seu ver, resultado de seus três momentos ou dimensões, mas com a genética determinada pela sua tensão complementar.

Reale ressalta que, em trabalhos anteriores ao seu, Sauer e Hall tentaram desenvolver um tridimensionalismo, o qual, no entanto, teriam falhado em demonstrar "[...] como é que os três elementos se correlacionam 'na unidade essencial à experiência jurídica', pois sem unidade de integração não há 'dimensões', mas simples 'perspectivas' ou 'pontos de vista'” ${ }^{20}$. Na teoria realeana, as três dimensões do Direito não se separam, mas estão em constante cooperação para que o Direito se revele, em seu modo integral. Como destaca, há uma

\section{[...] 'implicação-polaridade' existente entre fato e valor, de cuja tensão resulta o momento normativo, como solução superadora e integrante nos limites circunstanciais de lugar e de tempo (concreção histórica do processo jurídico, numa dialética de complementaridade) ${ }^{21}$.}

\footnotetext{
${ }^{19}$ Aqui, ateremo-nos ao que Reale entende por ontognoseologia e criticismo ontognoseológico, dispensando, assim, uma noção abstrata e desvinculada de sua teoria deste termo. Adiante, veremos em que consiste tal perspectiva.

${ }^{20}$ REALE, Miguel. Teoria tridimensional do direito. 5. ed. rev. e reestruturada. São Paulo: Saraiva, 1994, p.50. A elaboração da proposta tricotômica realeana se deu, primariamente, nos escritos constantes de suas obras Fundamentos de Direito (1940) e Teoria do Direito e do Estado (1940), que assistiram o nascimento de correntes análogas, a exemplo das doutrinas de Wilhelm Sauer (Juristiche Methodenlehre. Alemanha, 1940) e, anos mais tarde, Jerome Hall (Integrative Jurisprudence, in Interpretations of Modern Legal Philosophies - 1947 -, Living Law of a Democratic Society - 1949 - e Reason and Reality in Jurisprudence - 1958). Entretanto, Reale afirma que tais concepções já se movimentam numa forma de pensar semelhante à sua, já que deixam de lado a apreciação dos elementos (fato, valor e norma) separada e isoladamente (e aqui está o grande avanço com relação às tricotomias abstratas), de modo a concebê-los como perspectivas (Sauer e Hall), ou como fatores $e$ momentos (Reale e Recaséns) inilimináveis do direito, apesar de não unir as três dimensões numa tensão dialética, como o faz Reale.

${ }^{21}$ REALE, Miguel. Teoria tridimensional do direito. 5. ed. rev. e reestruturada. São Paulo: Saraiva, 1994, p. 57.
} 
Reale destaca que a abordagem dos valores no Direito se dá por um culturalismo tradicional, de matriz neokantiana ou firmada a partir do ontologismo axiológico de Scheler e N. Hartmann ${ }^{22}$. Ele se propõe a afirmar a categoria dos valores como categoria autônoma e emancipada, retirando-os do rol dos objetos ideais e, assim, ultrapassando fase anterior de seu próprio trabalho, que ele mesmo denomina tridimensionalismo bidimensionalista ${ }^{23}$.

O autor realiza, dessa forma, uma revisão compreensiva da noção de experiência jurídica como modalidade de experiência histórico-cultural, na qual o valor assume uma tríplice função: a) função ôntica: atua como um dos fatores constitutivos da realidade histórico-cultural; b) função gnoseológica: atua como prisma de compreensão da realidade que constitui, e c) função deontológica: atua como razão que determina a conduta. A partir dessa tríplice natureza do valor, portanto, Reale tenta deduzir ser o direito uma realidade in fieri, a qual reflete, em sua forma dinâmica, "[...] a historicidade mesma do ser do homem, que é o único ente que, de maneira originária, é enquanto deve ser, sendo o valor da pessoa a condição transcendental de toda a experiência ético-jurídica (personalismo axiológico)" 24 .

Nesse passo, o que Reale põe em destaque é que a pessoa é o valor para o qual todos os valores se orientam, e do qual todos eles podem surgir. Isto porque, em suas palavras, 0 ser do homem é o seu dever ser ${ }^{25}$, isto é, o dever ser assume condição sintética a priori no ser do homem, como possibilidade e condição de esse compreender o mundo e construí-lo a partir da objetivação de sua intencionalidade racional. É a pessoa, desse modo, o valor transcendental e a priori ante a toda experiência de objetivação.

${ }^{22} \mathrm{O}$ ontologismo axiológico traduz a perspectiva ética material dos valores que assumem Scheler e Hartmann, oposta à denominada ética formal sustentada por Kant. Essa perspectiva está profundamente ligada à fenomenologia de base husserleana e à filosofia dos valores. Tal perspectiva tem os valores como realidades absolutas, que independem da existência e que são de origem a priori. Conforme Scheler, os valores vivem num mundo separado do mundo do ser, e são produzidos pelo sujeito enquanto construção objetiva, de modo que só o conhecimento dos valores seria relativo. Hartmann, a seu turno, ressalta que os valores traduzem essências (ideias), na acepção que Platão confere a esse termo, de modo a não se enraizarem nas coisas e não poderem ser captados pelo pensamento. Assim, na ótica de Hartmann, não seriam os valores produto dos processos históricos, mas objetos ideais, que antecedem a tais processos, acessíveis intuitivamente pelo homem. Seriam, portanto, os valores, descobertas, feitas pelo homem e não criação histórica. Nesse sentido, veja-se a obra: SCHELER, Max. Ética: nuevo ensayo de fundamentación de un personalismo ético. Traducción de Hilario Rodríguez Sanz. Madrid: Caparrós Editores, 2001. (Colección Esprit).

${ }^{23} \mathrm{O}$ próprio Reale destaca que, antes de abrir os olhos para a noção de valor como elemento intercalar que une o ser ao dever ser, a sua teoria ainda não havia ultrapassado os limites de um tridimensionalismo vulgar. Sequer era assim denominada a sua forma de pensar, a qual ganha essa intitulação a partir de estudos ulteriores.

${ }^{24}$ REALE, Miguel. Teoria tridimensional do direito. 5. ed. rev. e reestruturada. São Paulo: Saraiva, 1994, p.63.

${ }^{25}$ REALE, Miguel. Introdução à filosofia. 4. ed São Paulo: Saraiva, 2002. 
Para tanto, o autor ressalta a necessidade de um Direito como experiência que se desenvolva, no plano epistemológico, como experiência cognoscitiva, em que há coimplicação entre sujeito e objeto - o que chama criticismo ontognoseológico e, no plano deontológico, não incorra no equívoco de setorizar valores, de modo a atender à solidariedade que une entre si todos eles. Ademais, há que se considerar, como aponta Reale $^{26}$, que haja uma orientação metodológica própria a qual pretenda superar a reflexão fenomenológica husserleana, substituindo-a pelo que chama reflexão fundamental ao modo crítico-histórico que se funda na "[...] correspondência entre a intencionalidade da consciência e o significado das 'intencionalidades objetivadas' pela espécie humana no processo da experiência histórico-cultural” ${ }^{27}$. Nessa esteira de ideias, é imperioso destacar duas noções fundamentais ao atingimento do escopo de nossa tarefa, quais sejam a de valor e a de dialética da complementaridade - já que aquela se deduz dessa última e não abstratamente, conforme já demonstrado nas linhas que dedicamos à teoria realena, como um de seus pressupostos.

Assim, lancemo-nos, primariamente, no estudo da proposta dialética realena, de modo a dar as condições basilares para que sua noção de valor se mostre adequadamente. Abordaremos, também, a concepção de valor na teoria dos objetos e o movimento feito por Reale em sua teoria tridimensional, ao retirá-la do plano dos objetos ideais, para fundar suas noções próprias de valor, cultura e dialética.

\title{
3. Dialética da Complementaridade e Valor em Miguel Reale
}

\begin{abstract}
Os caminhos e meios das ciências nunca poderão atingir a essência da ciência. Todavia, como ser pensante, todo pesquisador e mestre da ciência, todo homem, que atravessa uma ciência, pode mover-se em diferentes níveis do sentido e manter-lhe sempre vivo o pensamento ${ }^{28}$.
\end{abstract}

Martin Heidegger.

Apesar da concepção tridimensional de Direito proposta por Reale se enquadrar na tradição culturalista, ele mesmo advoga não comungar nesta tradição por emprestar

${ }^{26}$ REALE, Miguel. Teoria tridimensional do direito. 5. ed. rev. e reestruturada. São Paulo: Saraiva, 1994.

27 Ibid., p.63.

${ }^{28}$ HEIDEGGER, M. Ensaios e conferências. 8.ed. Petrópolis: Vozes; Bragança Paulista: Editora Universitária São Francisco, 2012.

Revista Publicum

Rio de Janeiro, v.2, n. 2, 2016, p. 169-204

http://www.e-publicacoes.uerj.br/index.php/publicum

DOI: 10.12957/publicum.2016.22557 
particularidades ao seu modo de ver o Direito ${ }^{29}$. É, pois, necessário investigar a legitimidade e possiblidade desse rompimento, para que possamos compreender corretamente o dialeticismo de seu pensamento e a noção de valor que dele emerge. Para tanto, é elementar recorrer às raízes genealógicas do culturalismo jurídico, as quais nos remetem aos teóricos da escola de Baden, da qual fazem parte Emil Lak e Gustav Radbruch, já mencionados nesse trabalho, como pioneiros na concepção trina acerca do Direito. ${ }^{30}$ Reale destaca nesse passo, como atitude meritória daquela escola ${ }^{31}$, “[...] ter percebido que, não obstante o corte feito por Kant entre ser e dever ser, havia no kantismo um elemento-chave para a compreensão do mundo histórico: o conceito de valor" ${ }^{32}$.

São a partir dos estudos da escola de Baden que se desenvolveram as diversas espécies de culturalismo jurídico, em torno da mediação entre fato e valor ${ }^{33}$. Entretanto,

${ }^{29} \mathrm{O}$ culturalismo tradicional corresponde à tradição neokantiana da escola de Baden, representada por Lask e Radbruch, como já salientado acima. Esse modo de ver concebe a cultura como elemento de mediação entre o mundo das intencionalidades objetivadas e o mundo dos a priori. A seu turno, o culturalismo realeano assume status diferenciado por não se utilizar da cultura, mas do valor como elemento de mediação na correlação sujeito-objeto, a que chama perspectiva ontognoseológica. Nesta vertente, o tridimensionalismo de Reale insere-se no âmbito do culturalismo jurídico, que segundo Gonzalez (em seu artigo A Teoria Tridimensional do Direito de Miguel Reale e o novo Código Civil Brasileiro, 2000) é uma corrente que nasce influenciada pelo pensamento de Kant, em específico das posições neokantianas da escola de Baden. Para Reale a experiência jurídica é parte da experiência cultural, isto é, decorre do processo existencial dos indivíduos e da coletividade, é integrante do que Edmund Husserl denominava Lebenswelt. Dessa forma, a cultura, é vista por Reale como projeção histórica da consciência intencional, isto é, como o mundo das intencionalidades objetivadas no tempo historicamente vivido. $O$ caráter específico e dialético da Teoria Tridimensional do Direito resulta, conforme salienta Reale, da compreensão ontognoseológica da experiência jurídica. Tal experiência se põe como objetivação da história, quando avaliada sob o enfoque ético/praxis. Noutra elocução, o homem é na sua raiz um ser histórico-axiológico, é um dever ser, um projetar-se axiológico na história. Para Reale, sendo o mundo da cultura o mundo das intencionalidades objetivadas, dos atos objetivados no tempo, o homem é o único ente que de forma originária e fundante, é o dever ser; ou melhor: "o ser do homem é o seu dever ser", por onde se vê que o "[...] processo "históricocultural' e 'processo ontognoseológico' são [...] uma única compreensão dialética, fundada no espírito como 'síntese a priori'.". REALE, Miguel. Teoria tridimensional do direito. 5. ed. rev. e reestruturada. São Paulo: Saraiva, 1994, p. 80.

${ }^{30}$ Assim, como destaca Reale sobre questão do desenvolvimento da filosofia da cultura, "[...] é da apreciação da Escola de Baden que devemos partir para situarmos a questão com a devida perspectiva histórica". Ibid., p.69.

${ }^{31} \mathrm{~A}$ essa escola se filiaram os teóricos tricotomistas Lask e Radbruch, como observa Reale. Apesar de “[...] ambos ainda conceberem o mundo jurídico à luz da 'Filosofia dos Valores', a qual assinala o ponto extremo a que podia chegar o formalismo ético neokantiano. [Além disso, ainda ressalta que ] [...] representou um grande passo a ideia dos neokantianos de interpor, entre realidade e valor, um elemento de conexão: a cultura, significando o complexo das realidades valiosas, ou, como esclarece Radbruch, 'referidas a valores'”. REALE, Miguel. Teoria tridimensional do direito. 5. ed. rev. e reestruturada. São Paulo: Saraiva, 1994, p. 70.

32lbid., p.69-70.

${ }^{33}$ Destaca Reale que as diversas espécies de culturalismo almejavam saber como a realidade valiosa se relacionava com os valores "[...] através de mônadas de valor, dirá Sauer; mediante 'categorias constitutivas', sugerirá Lask [...] ou, então, para negar a possibilidade de qualquer correlação entre eles (Radbruch, na primeira fase de seu pensamento, considerava-os gnoseologicamente antinômicos e irreconciliáveis, só admitindo uma composição relativa no momento da práxis), ou ainda, para determinar-se a 'função' desempenhada por cada um dos referidos elementos no contexto 
como destaca Reale ${ }^{34}$, o tridimensionalismo que se desenvolveu sob o lastro culturalista de matriz neokantiana não ultrapassou o seu estado latente, pois permanecera preso à estatização e abstração decorrente dos imperativos de seu formalismo ético, razão que o leva a considerar impertinente a procedência de tal doutrina da cultura como elemento intercalar ${ }^{35}$.

Propõe Reale um movimento de superação desse modo de pensar, sustentado que

[...] se partirmos do conceito husserleano de "intencionalidade da consciência", ou seja, de que conhecer é sempre conhecer algo, passa a ser focalizada sob nova luz a tão reiterada afirmação da heterogeneidade entre sujeito e objeto, a qual, no fundo, pressupõe um dualismo radical entre natureza e espírito, quando, efetivamente, $o$ que há no plano do conhecimento, é uma correlação transcendental subjetivo-objetiva, ou ontognoseológica, que não permite se reduza o sujeito ao objeto, ou vice-versa, visto como algo haverá sempre a atualizar-se no tocante à subjetividade, através de sínteses empíricas que se ordenam progressivamente no processo cognoscitivo ${ }^{36}$.

É nesta perspectiva ontognoseológica que reside o aspecto dialético (e diferenciador) da tricotomia realeana, o qual ele mesmo denomina enfaticamente de dialética da complementaridade $^{37}$. Nesta orientação epistemológica, pretende compreender tanto a dialética dos opostos do tipo hegeliano-marxista, quanto a análise fenomenológica de seus termos, tendo como lastro a estrutura polar dos valores. Como formula:

ontognoseológico de cada momento da experiência jurídica". REALE, Miguel. Teoria tridimensional do direito. 5. ed. rev. e reestruturada. São Paulo: Saraiva, 1994, p.70-1.

34 Ibid., p.71.

${ }^{35}$ Assim enuncia "Desde o primeiro contato com a Filosofia dos Valores, convenci-me da improcedência da doutrina da cultura como elemento intercalar, inserido entre a natureza e o valor, parecendo-me o resultado de um processo cognoscitivo abstrato, que não correlaciona devidamente sujeito e objeto como termos que se exigem reciprocamente numa relação de complementaridade, além de não superar outro abismo, o posto entre ser e dever ser na vertente ética da ação". Ibid., p.71.

36lbid., p.72.

${ }^{37}$ COELHO, Luiz Fernando. Crítica do direito e criticismo ontognoseológico (em homenagem a Miguel Reale). Sequência: Estudos Jurídicos e Políticos. Florianópolis, p. 120-132, jan. 1981. ISSN 2177-7055. Disponível em: <https://periodicos.ufsc.br/index.php/sequencia/article/view/17238>. Acesso em: 23 fev. 2016. 
No âmbito da dialética de complementaridade, dá-se a implicação dos opostos na medida em que se desoculta e se revela a aparência da contradição, sem que com este desocultamento os termos cessem de ser contrários, cada qual idêntico a si mesmo e ambos em mútua e necessária correlação 38 .

Assim, conclui o autor que o valor, e não a cultura, figura como elemento de mediação também no plano gnoseológico, o que possibilita a relação sujeito-objeto, tornando-se objeto, o valor, mediante a intencionalidade da consciência, na qual surge como objeto valioso. A partir disso, afirma ser o conhecimento uma síntese ontognoseológica, a qual vem acompanhada pela consciência da validade da correlação alcançada, de maneira que, determinados valores resultam de um valor primordial que condiciona e possibilita o processo gnoseológico. Esse valor fundante funciona como mecanismo a priori, na conotação que Kant empresta a essa palavra, que possibilita ao homem sua capacidade de síntese, isto é, de conhecer ${ }^{39}$. É, portanto, o valor fundante a essência do espírito, enquanto síntese originária ou transcendental. Além disso, como alhures mencionado, Reale ainda concebe o valor numa perspectiva diferente da sustentada pelos precursores da teoria dos objetos (Scheler e Hartmann ${ }^{40}$ ), o que é fundamental para

${ }^{38}$ Ainda observa que é "[...] da estrutura mesma dos valores, como entidades polares, que resulta a dialeticidade de todos os 'bens culturais' que a espécie humana constitui na faina histórica de dar valor às coisas e aos atos, constituindo, graças ao mundo da natureza dada, o mundo históricocultural". REALE, Miguel. Teoria tridimensional do direito. 5. ed. rev. e reestruturada. São Paulo: Saraiva, 1994, p. 73.

${ }^{39}$ Salvo melhor juízo, não é outra a interpretação que se faz da seguinte passagem: "O conhecimento é (...) uma síntese ontognoseológica, acompanhada da consciência da validade da correlação alcançada, sendo certo que os valores, que se revelam no ato de conhecer, são resultantes de um valor primordial e fundante, sem cujo pressuposto a priori - e, neste ponto, a lição de Kant afigurase-me imprescindível - não seria logicamente pensável sequer o processo gnoseológico: é o valor essencial do espírito como 'síntese a priori', ou, por outras palavras, a compreensão da consciência como possibilidade originária de síntese. A correlação sujeito-objeto põe-se, desse modo, como 'síntese transcendental' e condição possibilitante das sínteses empírico-positivas que constituem a trama da experiência humana". REALE, Miguel. Teoria tridimensional do direito. 5. ed. rev. e reestruturada. São Paulo: Saraiva, 1994, p.73.

${ }^{40} \mathrm{~A}$ Teoria dos Objetos, desenvolvida por Max Scheler e Nicolai Hartmann sob as influências de Husserl (que parte de Brentano), classifica os objetos em duas amplas categorias, a saber: a) objetos naturais (físicos ou psíquicos) e b) objetos ideais. Seriam naturais aqueles que não podem ser concebidos sem referência ao espaço e ao tempo ou, mais rigorosamente, ao espaço-tempo, de certo modo dados pela natureza e não construídos pelo homem. Podem ser físicos (ou reais) dotados de espaçotemporalidade, ou psíquicos dotados apenas de temporalidade, destituídos de espacialidade, isto é, corporeidade, de modo a depender de um objeto físico para se manifestar, e que são exemplos as sensações e emoções. Além disso, o acesso espiritual até as determinações ou qualidades em ambas as categorias de objetos se dá pelo princípio da causalidade, visto que se processam, em geral, conforme nexos constantes de antecedente e consequente. Já os objetos ideais, por outro lado, são aqueles objetos a-espaciais e atemporais, isto é, puramente ideais, só existem enquanto pensados. São chamados de objetos ideados visto que existem apenas na mente humanas. Nessa categoria,

Revista Publicum

Rio de Janeiro, v.2, n. 2, 2016, p. 169-204

http://www.e-publicacoes.uerj.br/index.php/publicum

DOI: $10.12957 /$ publicum.2016.22557 
a sua nova compreensão de cultura ${ }^{41}$ e para a formulação adequada da noção de valor como objeto de categoria especial, nem situado no rol de objetos ideais, como propunham os teóricos acima referidos; nem no rol de objetos naturais.

Assim, tenta demonstrar que os valores são expressões objetivadas do dever ser, enquanto ser mesmo do homem, razão de não poderem se incluir no rol de objetos ideais, já que atuantes como elemento intercalar no plano gnoseológico. Por isso, qualifica-os como categorias emancipadas e autônomas, que possibilitam a relação sujeito-objeto. Os valores possuem, nessa perspectiva, realidade atemporal e a-espacial, ou seja, apresentam um modo de ser insubordinado ao espaço-tempo, à semelhança dos objetos ideais. Porém enquanto os objetos ideais valem, independentemente de qualquer coisa que ocorra no espaço e no tempo, os valores só são concebidos em função de algo existente: as coisas valiosas. Assim, os valores, diferente dos objetos ideais, não admitem quaisquer possibilidades de quantificação. Nesse sentido afirma Reale que não se "[...] trata, pois, de mera falta de temporalidade e de espacialidade, mas, ao contrário, de uma impossibilidade absoluta de mensuração. Não se numera, não se quantifica o valioso" ${ }^{42}$.

Reale compreende todos os objetos, sejam naturais ou ideais, ou ainda autônomos, no mesmo gênero de objetos culturais, e destaca a cultura como elemento integrante de tais objetos a partir de uma interação dialética entre ser e dever-ser.

Nesse caminhar, já conseguimos visualizar a noção de cultura realeana, que se expressa como o processo de sínteses progressivas que o espírito vai realizando a partir da compreensão operacional da natureza, e não como elemento que intercala essas duas

incluíam-se os valores. REALE, Miguel. Filosofia do direito. 17. ed. São Paulo: Saraiva, 1996. Assim, como destaca Reale "[...] Scheler e N. Hartman inclinaram-se a volver às raízes platônicas do problema, concebendo os valores como objetos ideais, - com isso, repeliam sua redução a objetos naturais, de ordem psicológica ou sociológica, com a afirmação, no fundo de inspiração kantiana, de que há duas e apenas duas linhas primordiais de pensamento, o Ser e o Valor, de tal modo que, assim como afirma-se que Ser é o que é dever-se-ia dizer: Valor é o que vale, sem ser possível ir além desses enunciados intuitivos primordiais (...). Ora, ao longo de minha meditação sobre a problemática axiológica, que é central em meu pensamento, não me convenci da necessidade da conversão dos valores em idealidades, em arquétipos platônicos, para assegurar aos homens liberdade de opções e de caminhos, rasgando novos horizontes. ". REALE, Miguel. Invariantes axiológicas. Estudos Avançados, São Paulo, v. 5, n. 13, p. 131-144, dec. 1991. ISSN 1806-9592. Disponível em: <http://www.revistas.usp.br/eav/article/view/8625>. Acesso em: 25 feb. 2016. doi:http://dx.doi.org/10.1590/S0103-40141991000300008.

${ }^{41}$ Segundo o professor Coelho, a doutrina realena traduz um culturalismo fenomenológico. COELHO, Luiz Fernando. Crítica do direito e criticismo ontognoseológico (em homenagem a Miguel Reale). Sequência: Estudos Jurídicos e Políticos, Florianópolis, p. 120-132, jan. 1981. ISSN 2177-7055. Disponível em: <https://periodicos.ufsc.br/index.php/sequencia/article/view/17238/15811>. Acesso em: 24 fev. 2016.

${ }^{42}$ REALE, Miguel. Filosofia do direito. 17. ed. São Paulo: Saraiva, 1996, p. 187. 
dimensões ${ }^{43}$. É, portanto, a cultura resultado da objetivação espiritual - isto é, afigura como o mundo das intencionalidades objetivadas, como também a experiência jurídica, de onde decorre a sustentação de que o Direito deve ser visto como vida humana objetivada. No plano ético, por conseguinte, o processo ontognoseológico deve ser visto como objetivação histórica, em termos de experiência axiológica - historicismo axiológico. Nesse viés, destaca:

Assim como no plano gnoseológico, sujeito e objeto se implicam e se correlacionam, ontognoseologicamente, sem que um termo possa reduzir ao outro, e sem que, ao mesmo tempo, um deles seja pensável sem o outro (polaridade gnoseológica entre subjetividade $e$ objetividade), da mesma forma o homem, na raiz de seu ser histórico, é enquanto deve ser, mas jamais a sua existência esgota as virtualidades de seu projetar-se temporal-axiológico, nem os valores são concebíveis extrapolados ou abstraídos do existir histórico (polaridade ética entre ser e dever ser). Por onde se vê que "processo histórico-cultural" e "processo ontognoseológico" são dois momentos de uma única compreensão dialética, fundada no espírito como "síntese a priori" 44.

Noutros termos, pode-se afirmar, a partir da ótica realeana, que a cultura, a história e o direito são expressões objetivas, isto é, em ato, daquilo que o homem é em sua essência mesma, potência ${ }^{45}$, enquanto fonte de todos os valores ${ }^{46}$. São, dessa forma, o direito e também os valores que o permeiam, entes que refletem o ser do homem, atualizados em sua temporalidade, sendo guiados pela sua pessoalidade. A esse fenômeno, denomina Reale de abertura angular axiológica da pessoa ${ }^{47}$. Assim é que se deve compreender a

${ }^{43}$ REALE, Miguel. O direito como experiência: introdução à epistemologia jurídica. 2. ed. São Paulo: Saraiva, 1992.

${ }^{44}$ REALE, Miguel. Teoria tridimensional do direito. 5. ed. rev. e reestruturada. São Paulo: Saraiva, 1994, p.81.

${ }^{45}$ Aqui nos valemos das noções de ato e potência Aristotélicas. GHIRALDELLI JÚNIOR, P. A Aventura da Filosofia: de Parmênides a Nietzsche. São Paulo: Manole, 2010. Para aprofundar, recomendamos a leitura de ARISTÓTELES. Metafísica. São Paulo: Edições Loyola, 2002.

${ }^{46}$ Observa Reale que "No fundo há dois valores que merecem ser lembrados concomitantemente, não obstantes suas renovadas antinomias: a logicidade e a historicidade do ser humano. É em virtude desses dois valores constitutivos do homem, que este não só pensa mas torna objetivo, extrapola de si aquilo que pensa, convertendo em 'objetividades' as 'intencionalidades' que são próprias de sua consciência". REALE, Miguel. Teoria tridimensional do direito. 5. ed. rev. e reestruturada. São Paulo: Saraiva, 1994, p.106.

${ }^{47} \mathrm{Em}$ sentido semelhante Reale "No centro de nossa concepção axiológica situa-se, pois, a ideia do homem como ente que, a um só tempo, é e deve ser, tendo consciência dessa dignidade. É dessa autoconsciência que nasce a ideia de pessoa, segundo a qual não se é homem pelo mero fato de 
afirmação de Reale de que o "[...] revelar-se do homem a si mesmo já é em si e por si um valor, a fonte de todos os valores. O ser do homem é, repito, de maneira originária, e não derivada, o seu dever ser: é dessa raiz que se origina, na pluralidade de suas formas, a árvore da vida cultural" ${ }^{48}$. Em máxima síntese, é o Direito a expressão objetivada do espírito ${ }^{49}$ mesmo do homem, o qual está fatalmente imerso no mundo da vida (lebenswelt) ${ }^{50}$, que é seu condicionante e condicionado. Ocorre que, conforme assevera Reale ${ }^{51}$, no acontecer da experiência histórica do homem emergem valores que podem estabilizar-se, isto é, petrificar como fundamentais. Nesse ponto, expressa Reale a sua inspiração jusnaturalista, embora numa perspectiva historicista ${ }^{52}$, no sentido a seguir expresso em sua literalidade:

[...] se não acolho a tese de um Direito Transcendente e a-histórico, reconheço que certo número de normas atua como transcendentalia da experiência jurídico-positiva. O Direito Natural Transcendental resulta, no meu entender, da constatação de que o homem, através do processo dialógico da história, vai tomando consciência de determinados valores fundamentais, como, por exemplo, o da inviolabilidade da pessoa humana, os quais, uma vez trazidos à luz da consciência histórica, são considerados intangíveis (...), na experiência ético-jurídica dá-se o advento de "invariantes axiológicas", isto é, de exigências axiológicas constantes $e$ inamovíveis por serem consideradas da essência mesma do ser humano: são as constantes

existir, mas pelo significado ou sentido da existência. Quando apreciamos o problema do homem, toda Ontologia se resolve em Axiologia, abrindo-se as perspectivas da Metafísica". REALE, Miguel. Filosofia do direito. 17. ed. São Paulo: Saraiva, 1996, p. 212..

48 REALE, Miguel.Teoria tridimensional do direito. 5. ed. rev. e reestruturada. São Paulo: Saraiva, 1994, p.82.

${ }^{49}$ Espírito aqui entendido nos limites da teoria realeana, que dispõe: "A compreensão do espírito como capacidade de síntese e o concomitante reconhecimento de quem diz síntese diz liberdade, constitui o pressuposto inamovível que condiciona qualquer meditação sobre o problema do homem e aquilo que o homem construiu e continua construindo através dos tempos, isto é, a sua experiência social e histórica. Poderia dizer que a compreensão do espírito como liberdade autoconsciente e como síntese representa o 'a priori' transcendental fundante da experiência histórica, em geral, e da experiência ético-jurídica em particular". Ibid., p. 84.

${ }^{50}$ Nesse sentido, predispõe Reale que "[...] desenvolvendo teses já implícitas no pensamento de Dilthey, retomou Husserl, em sua obra póstuma A Crise das Ciências Europeias e a Fenomenologia Transcendental, dando-Ihe novo e mais profundo sentido, o estudo do 'mundo da vida' (Lebenswelt)". Ibid., p.102.

51 Ibid., p.102.

${ }^{52}$ Não estamos conscientes da possiblidade da harmonização entre o jusnaturalismo realeano e sua filiação historicista. 
axiológicas transcendentais do Direito, porquanto, no fundo, foram elas que tornaram a experiência jurídica possível. ${ }^{53}$.

Está-se a falar sobre o que ele denomina invariantes (ou constantes) axiológicas, isto é, valores objetivados que tendem à estabilização e petrificação, como cânones norteadores da ordem jurídica. Constituem-se, em sua ótica, valores supremos que alçam a uma duração permanente. Assim, apesar de Reale não acolher expressamente a tese de um Direito Natural transcendente e a-histórico, reconhece que determinadas normas direcionadas a valores transcendentais, "[...] atuam como transcendentalia da experiência jurídicopositiva" ${ }^{54}$. Nesse sentido, consagra o seu personalismo axiológico, que é também um jusnaturalismo transcendental, já que, em suas palavras:

O Direito Natural Transcendental resulta [...] da constatação de que o homem, através do processo dialógico da história, vai tomando consciência de determinados valores fundamentais, como, por exemplo, o da inviolabilidade da pessoa humana, os quais, uma vez trazidos à luz da consciência histórica, são considerados intangíveis. Tenho dito que, assim como nas ciências biológicas se tem reconhecido a ocorrência de mutações que dão origem a "invariantes biológicas", até o ponto de parecerem "inatas", da mesma forma, na experiência ético-jurídica dá-se o advento de "invariantes axiológicas", isto é, de exigências axiológicas constantes e inamovíveis, por serem consideradas da essência mesma do ser humano: são as constantes axiológicas transcendentais do Direito, porquanto, no fundo, foram elas que tornaram a experiência jurídica possível ${ }^{55}$.

Desse modo, ao falar em "constatação histórica de valores fundamentais", Reale nos fornece, como pista, a intuição de que esses valores, para ele, já estariam dados, de algum modo. Caberia ao homem, pela história, isto é, mediante sua existência, abrir os olhos para esses valores já postos como fundamentais num plano a priori. Nesse ponto, expressa Reale a conotação transcendental de matriz kantiana de sua axiologia, vez que os valores, em seu modo de ver, afiguram como precedentes à própria existência do ente que somos, além de

${ }^{53}$ REALE, Miguel. Teoria tridimensional do direito. 5. ed. rev. e reestruturada. São Paulo: Saraiva, 1994, p.109.

${ }^{54}$ Ibid., p.110.

${ }^{5}$ Ibid., p.109.

Revista Publicum

Rio de Janeiro, v.2, n. 2, 2016, p. 169-204

http://www.e-publicacoes.uerj.br/index.php/publicum

DOI: 10.12957/publicum.2016.22557 
admitir que estes traduziriam a essência mesma do ser humano ao serem objetivados na história mediante a intencionalidade da consciência.

Após trilharmos o caminho pelas noções de dialética da complementaridade e valor em Reale, poderemos compreender, agora, a forma como o autor tridimensionalista caracteriza o valor no item seguinte, tendo em vista as matrizes filosófico-teoréticas de que se utiliza para fazer o seu movimento teórico.

\section{Entre Kant e Husserl: Interpretação Crítico-Fenomenológica da Noção entre Valor Realeana e os Limites de sua Pretensão Sintetizante}

\begin{abstract}
Uma autêntica filosofia política não poderá, em última instância, surgir a partir de uma análise de tendências, acomodações parciais, interpretações, ou, pelo contrário, da revolta contra a própria filosofia. ${ }^{56}$
\end{abstract}

Hannah Arendt.

O presente tópico segue assim denominado em razão de levarmos em consideração que Reale, ao propor sua noção própria de valor, vale-se das doutrinas filosóficas de Immanuel Kant e de Edmund Husserl. No entanto, reconhecemos não poder afirmar que o referido autor tridimensionalista seja filiado a essa ou àquela tradição filosófica, já que sua construção teórica parece adquirir feição peculiar. A seu turno, caso consideremos que Reale afirma ir além tanto de Husserl quanto de Kant, ao propor seu criticismo ontognoseológico, a titulação "Entre Kant e Husserl” já nos é suficiente para caracterizar seu pensamento, visto que nos parece forçoso o movimento por ele pretendido de unir jusnaturalismo transcendental à historicismo axiológico, o que nos leva a afirmar que Reale não supera os autores, mas fica entre eles e limitado. Vejamos, portanto, brevemente, em que consistem as doutrinas filosóficas de Kant e de Husserl, para que possamos seguir com tal interpretação.

\subsection{Immanuel Kant: o despertar do sono dogmático e a busca de uma metafísica científica.}

${ }^{56}$ ARENDT, Hannah. 0 interesse pela política no pensamento europeu recente. Disponível em: < http://www.oquenosfazpensar.com/adm/uploads/artigo/o_interesse_pela_politica_no_pensament o_filosofico_europeu_recente/n3hannah.pdf>. Acesso em: 24 fev. 2016. 
Para inferirmos alguma noção de valor da filosofia kantiana, é preciso perscrutar sua filosofia moral, inserida no bojo de sua filosofia como um todo, à qual nos proporemos visitar, a partir de agora, nos limites do objetivo deste trabalho. Reagindo às ideias propostas por David Hume ${ }^{57}$, Kant desperta do sono dogmático para indagar sobre os fundamentos de validade da metafísica e a pretensão do conhecimento verdadeiro ${ }^{58}$. Kant, assim, pretende demonstrar a impossibilidade dos conceitos metafísico-tradicionais para conhecer a realidade em si das coisas. Propõe, então, uma metafísica enquanto conhecimento de nossa capacidade de conhecer - Crítica da razão pura-, de modo a apreendermos a realidade como aquilo que existe para nós na qualidade de sujeitos cognoscentes ${ }^{59}$.

In suma, para o filósofo prussiano, o sujeito do conhecimento não seria psicológico e individual, como afirmara Hume, mas estruturalmente universal e idêntico para todos os seres humanos - categoria a que denomina Sujeito Transcendental-, assentado nos pressupostos de uma razão sintética a priori. A realidade em si mesma nunca seria, desse

${ }^{57}$ Afirmava Hume que o sujeito do conhecimento opera associando sensações, percepções e impressões recebidas pelos órgãos sensoriais e armazenadas na memória. Além disso, para ele, as ideias nada mais seriam do que hábitos mentais de associação de sensações, percepções e impressões, que afiguram como conteúdo da metafísica, já que expressam nomes gerais atribuídos aos hábitos psicológicos de associar os dados da sensação e da percepção. Assim, as substâncias ou essências seriam apenas imagens da consciência, e a causalidade, portanto, poderia ser definida como mero hábito da mente estabelecido por percepções sucessivas. Nessa perspectiva humeneana, as entidades metafísicas não existiriam. CHAUI, M. Convite à filosofia. 10. ed. São Paulo: Atica, 2000. Para aprofundar, vide HUME, David. Tratado da natureza humana. (Tradução de Déborah Danowski). São Paulo: Editora UNESP; Imprensa Oficial do Estado, 2001.

58“Até agora, diz Kant, a metafísica tem sido uma insensatez dogmática. Tem sido a pretensão de conhecer aqueles seres que, justamente, escapam de toda possibilidade humana de conhecimento, pois são seres aos quais não se aplicam as condições universais e necessárias dos juízos, isto é, espaço, tempo, causalidade, qualidade, quantidade, substancialidade, etc. Essa metafísica não é possível" CHAUI, M. Convite à filosofia. 10.ed. São Paulo: Atica, 2000, p. 297. E qual metafísica é possível? A que tem como objeto o estudo das condições de possibilidade de todo conhecimento humano e de toda a experiência humana possíveis. A metafísica que estuda, portanto, as condições universais e necessárias da objetividade em geral e não que estuda a essência do Ser, ou seja, "Ser enquanto Ser". OLSON, R. Introdução ao existencialismo. São Paulo: Editora Brasiliense, 1970. Sobre a possibilidade de uma metafísica em Kant v. KANT. Prolegómenos a toda a metafísica futura: que queira apresentarse como ciência. Lisboa: Edições 70, (19??).

${ }^{59}$ Kant afirmou que fizera uma revolução copernicana na filosofia ao demonstrar que as leis universais da natureza não estão nas próprias coisas, mas são padrões do pensamento humano impostos sobre as coisas. Visando distinguir entre as coisas como são em si e as coisas reelaboradas pela mente humana, o filósofo alemão lançou os termos nôumeno e fenômeno. Sendo o nôumeno o mundo das coisas em si, o mundo que não podemos conhecer, isto é, aquilo que não é dado à sensibilidade nem ao conhecimento, mas é afirmado pela razão. $O$ mundo fenomênico é o efetivamente presente à nossa mente, isto é, aquilo que se apresenta ao sujeito do conhecimento na experiência. A analogia com Copérnico é explicada pelo próprio Kant, visto que este "[...] não podendo prosseguir na explicação dos movimentos celestes enquanto admitia que toda a multidão de estrelas se movia em torno do espectador, tentou, objetivando melhor resultado, fazer antes girar o espectador e deixar os astros imóveis." KANT, Immanuel. Crítica da razão pura. São Paulo: Abril Cultural, 1980, p. 28-9. 
modo, conhecida, mas somente a sua feição fenomênica, que é organizada pelo sujeito que conhece de acordo com as formas do espaço e do tempo ${ }^{60}$. Como o próprio expõe:

Temos querido provar que todas as nossas intuições só são representações de fenômenos, que não percebemos as coisas como são em si mesmas, nem são as suas relações tais como se nos apresentam, e que se suprimíssemos nosso sujeito, ou simplesmente a constituição subjetiva dos nossos sentidos em geral, desapareceriam também todas as propriedades, todas as relações dos objetos no espaço e no tempo, e também o espaço e o tempo, porque tudo isto, como fenômeno, não pode existir em si, mas somente em nós mesmos. Para nós é completamente desconhecida qual possa ser a natureza das coisas em si, independentes de toda receptividade da nossa sensibilidade. Não conhecemos delas senão a maneira que temos de percebê-las; maneira que nos é peculiar; mas que tão pouco deve ser necessariamente a de todo ser, ainda que seja a de todos os homens ${ }^{61}$.

Nesse caminhar, o que está Kant a movimentar é a questão do fundamento da metafísica, já que nem o idealismo racionalista, nem o ceticismo empirista conseguem dar conta desse problema. É a partir da tensão entre tais doutrinas, em suas múltiplas manifestações, inclusive, que Kant irá conceber sua Crítica, a qual visa não a desaprovação de determinado modelo, mas solucionar o problema de ser possível ou não uma metafísica em geral, de modo a determinar suas fontes, extensão e limites, bem como os princípios que o seu modelo assegura ${ }^{62}$.

Em sua Crítica da razão pura (1781), Kant irá sustentar a possibilidade de formulação de juízos sintéticos a priori, a partir da análise de proposições aritméticas fornecida pela matemática. Assim, a matemática, em Kant, afigura como o caminho científico que leva à segurança. Como aponta Seibt, a "[...] exemplo da matemática e das ciências experimentais que surgem e alcançam resultados satisfatórios e estáveis, a filosofia defronta-se com a tarefa de encontrar também para si um solo mais confiável" 63 . Há, desse modo, uma

60 Ibid.

61 KANT, Immanuel. Crítica da razão pura. São Paulo: Abril Cultural, 1980, p.25.

62 CARNEIRO, W. A. Hermenêutica Jurídica Heterorreflexiva: uma teoria dialógica do direito. Livraria do Advogado: Porto Alegre, 2011.

63 SEIBT, Cezar. Elementos da crítica do jovem Heidegger a Kant e Husserl. Acta Scientiarum. Human and Social Sciences. 2011. Disponível em: <http://www.redalyc.org/articulo.oa?id=307325341004>. Acesso em: 23 fev. 2016. 
atribuição de valor considerável à cientificidade do conhecimento e, como se depreende da Crítica kantiana, é a essa cientificidade que a metafísica deverá se apegar para que possa alçar ao conhecimento verdadeiro.

Nesses moldes, tentará o filósofo responder a indagação da possibilidade de uma metafísica que se desamarre da dogmática racionalista e escape ao ceticismo empirista. Conforme assinala Carneiro, a "[...] resposta para essa questão passa por aquilo que ficou eternizado como 'revolução copernicana na filosofia'. Kant transfere para o sujeito transcendental o papel regulador do conhecimento a priori dos objetos." ${ }^{64}$. Dessa forma, os objetos do conhecimento são trazidos à luz pelo sujeito transcendental, estrutura pressuposta universal da razão humana. Kant afirma que o sujeito cognoscente é a condição necessária de possibilidade dos objetos do conhecimento. O conhecimento, assim, será transcendental quando se ocupar não propriamente dos objetos, mas da maneira que temos de conhecê-los, tanto quanto possível a priori ${ }^{65}$. Transcendental em Kant, como afirma Pascal é oposto a empírico, é o que não admite outro uso senão o imanente, isto é, relacionado aos objetos da experiência, ao sujeito que conhece ${ }^{66}$. Quer dizer: transcendental é o que participa do processo cognitivo, não estando no objeto, mas sim imanente ao sujeito do conhecimento; é o que possibilita o conhecimento a priori, ou seja, conhecimentos não retirados da experiência, mas os quais a experiência deve conformarse.

Em sua Crítica da razão pura, Kant constata o modo característico de conhecer da ciência, ou seja, busca os tipos de proposições presentes nas teorias científicas que possibilitaram seu progresso. Estabelece, dessa forma, a divisão entre a validade dos conhecimentos, a posteriori ou a priori, e entre os juízos, afirmações e proposições presentes na linguagem científica, analíticos e sintéticos. Assim, explicita:

Em todos os juízos em que se concebe a relação de um sujeito com um predicado [...], esta relação é possível de dois modos: ou o predicado $B$ pertence ao sujeito A como algo nele contido (de um modo tácito), ou $B$ é completamente estranho ao conceito $A$, se bem se ache enlaçado com ele. No primeiro caso chamo ao juízo analítico, no segundo, sintético ${ }^{67}$.

${ }^{64}$ CARNEIRO, W. A. Hermenêutica Jurídica Heterorreflexiva: uma teoria dialógica do direito. Livraria do Advogado: Porto Alegre, 2011, p.50.

65 KANT, Immanuel. Crítica da razão pura. São Paulo: Abril Cultural, 1980.

66 PASCAL, Georges. O pensamento de Kant. 6. ed. Petrópolis, RJ: Vozes, 1999.

${ }^{67}$ KANT, Immanuel. Crítica da razão pura. São Paulo: Abril Cultural, 1980, p.7.

Revista Publicum

Rio de Janeiro, v.2, n. 2, 2016, p. 169-204

http://www.e-publicacoes.uerj.br/index.php/publicum

DOI: $10.12957 /$ publicum.2016.22557 
De forma sucinta, convém elucidar, conforme Kant, que há na ciência três tipos de juízos são eles: analítico a priori - o predicado não traz nenhuma informação nova sobre o sujeito, isto é, o predicado está previamente posto no sujeito (princípio da identidade, universal e necessário); sintéticos a posteriori - tais preposições trazem uma nova informação não dada previamente pelo sujeito, tendo sua veracidade sustentada pela experiência, não é universal, mas circunstancial; e sintéticos a priori - o predicado traz uma informação nova que não está sustentada na experiência, mas tem sua veracidade validada na razão transcendental. As perguntas nevrálgicas da Crítica da razão pura são: como são possíveis juízos sintéticos a priori? Como é possível sustentar que a razão pura pode validar conhecimento verdadeiro sobre o mundo? Como é possível conhecimento que se aplica ao mundo, mas não provém da experiência? ${ }^{68}$

Assim, na modernidade, dados os reclames de segurança e certeza, serve o Sujeito Transcendental kantiano como cerne de onde se deflui a validade de toda a experiência, o qual afigura como estrutura universal e atemporal ${ }^{69}$. É nessa tentativa de fundamentação do modo de pensar metafísico, inclusive, que Kant tentará sintetizar os espaços de distanciamento entre o racionalismo e o empirismo, já que desenvolve "[...] uma teoria na qual o aparelho cognitivo representa o elemento inato da razão, a ser preenchido com a experiência" 70 .

O giro copernicano realizado por Kant abarca não só a indagação “o que posso conhecer?", desdobrada na Crítica da razão pura, mas também o questionamento "o que devo fazer?", desenvolvida na Crítica da razão prática; isto é, Kant ${ }^{71}$ não somente busca compreender o mundo do conhecimento, mas também o da ação, com implicações na moral prática.

Para Kant, a razão prática, aquela exercida de forma prática, é a capacidade que o homem tem de escolher sua ação, isto é, sua faculdade de querer, sua vontade. É a faculdade, que dispõe o homem, de agir conforme determinadas regras. É, segundo Höffe,

68 Para aprofundar na explicação kantiana sobre a fundamentação e validade dos juízos sintéticos $a$ priori, ver KANT, Immanuel. Crítica da razão pura. São Paulo: Abril Cultural, 1980.

${ }^{69}$ Como denuncia Seibt uma "[...] das diferenças entre Kant e Heidegger é que para o primeiro a forma, a consciência, determina o conteúdo através de uma estrutura universal e atemporal. Para Heidegger tanto a forma como o conteúdo se co-determinam e com isso criam um 'aí' indepassável. Também por isso não há separação originária entre consciência e mundo. Heidegger coloca a consciência no tempo e ela em conexão íntima com os eventos e entes com que se relaciona, a partir do princípio da intencionalidade". SEIBT, Cezar. Elementos da crítica do jovem Heidegger a Kant e Husserl. Acta Scientiarum. Human and Social Sciences. 2011. Disponível em: <http://www.redalyc.org/articulo.oa?id=307325341004>. Acesso em: 23 fev. 2016.

70lbid.

${ }^{71}$ HÖFFE, Otfried. Immanuel Kant. São Paulo: Martins Fontes, 2005. 
pela vontade que o homem se distingue dos demais animais, que agem conforme o instinto, as leis dadas naturalmente e os impulsos de uma vontade da natureza e não uma vontade própria. Nesta continuidade, afirma o filósofo prussiano que o homem é o detentor dessa vontade própria:

Tudo na natureza age segundo leis. Só um ser racional tem a capacidade de agir segundo a representação das leis, isto é, segundo principios, ou: só ele tem uma vontade. Como para derivar as aç̧ões das leis é necessária a razão, a vontade não é outra coisa senão razão prática. $^{72}$

Assim, Kant busca encontrar nos costumes a lei interna do homem que regula sua vontade livre - o homem tem ambiguidade, ou seja, há nele algo que escapa às leis naturais, conquanto pode agir à revelia dos impulsos internos. Tal lei constitui a moralidade, que reivindica validade universal, objetiva e atemporal ${ }^{73}$. Em Fundamentação da metafísica dos costumes, Kant deslinda pela busca do princípio moral supremo. Assim, afirma categoricamente que não há coisas boas absolutamente, mas seu valor está condicionado ao uso que delas se faça. Exemplifica que até determinadas qualidades superiores como a reflexão ou o autodomínio só podem ser consideradas boas verdadeiramente quando a serviço de uma boa vontade estiverem. Mas o que torna uma vontade verdadeiramente boa? Responde Kant: a própria natureza do querer. Aclara que

\begin{abstract}
A boa vontade não é boa por aquilo que promove ou realiza, pela aptidão para alcançar qualquer finalidade proposta, mas tão-somente pelo querer, isto é, em si mesma, e, considerada em si mesma, deve ser avaliada em grau muito mais alto do que tudo o que por seu intermédio possa ser alcançado em proveito de qualquer inclinação, ou mesmo, se se quiser da soma de todas as inclinações ${ }^{74}$.
\end{abstract}

Sendo assim, segundo Kant, só merece ser identificada como estando à altura do valor moral, a boa vontade. Nas palavras do filósofo: "neste mundo, e até também fora

\footnotetext{
72 KANT, Immanuel. Critica da razão prática. Rio de Janeiro: Martins Fontes, 1984, p. 69.

73 KANT, Immanuel. Fundamentação da metafisica dos costumes. Lisboa: Edições 70, 19(--).

${ }^{74}$ KANT, Immanuel. Fundamentação da metafisica dos costumes. São Paulo: Cia. Ed. Nacional, 1964, p. 23. 
dele, nada é possível pensar que possa ser considerado como bom sem limitação a não ser uma só coisa: uma boa vontade.". ${ }^{75}$

Deslinda, Kant, que para desenvolver, porém, o conceito de uma boa vontade altamente estimável em si mesma e sem qualquer intenção ulterior, é preciso encarar o conceito do Dever, que contém em si o de boa vontade. Dessa forma, ao elucidar a moral com suporte no conceito de dever, Kant procura compreender o homem enquanto ser moral. Visto que o dever é a moralidade na configuração de preceito, mandamento, do imperativo. Aclara Höffe que em Kant, a forma imperativa só tem um sentido para os sujeitos cuja vontade não é boa, necessariamente. "Só se pode falar de dever onde há, ao lado de um apetite racional, ainda impulsos concorrentes das inclinações naturais, onde há, ao lado de um querer bom, ainda um querer ruim ou mau." 76 .

Ao apresentar o conceito de dever, Kant acautela que agir em conformidade com o dever difere de agir por dever. Nas ações que são exercidas em conformidade ao dever, os homens não sentem, deveras, inclinação imediata, mas agem por impulso de algum interesse, nas palavras de Kant: "impulsos de outra tendência [...] cálculo interesseiro." 77. Já nas ações que são verdadeiramente realizadas por dever, os homens agem de forma desinteressada, agem sem inclinações ou impulsos interesseiros, fazem o bem, não por cálculo de interesse, mas por dever. São as ações que possuem verdadeiro valor moral. Agir por dever é uma autonomia do ser racional, de agir de forma desinteressada, sem tendências ou inclinações. A partir de Kant é possível afirmar que o valor moral reside na intenção pura, no emprego do esforço necessário para realiza-la, reside na boa vontade; esta é a primeira proposição do valor moral na ética kantiana. Mas não só.

Venhamos à segunda proposição. Uma ação cumprida por dever tira seu valor moral não do fim que por ela deve ser alcançado, mas da máxima que a determina. Este valor não depende, portanto, da realidade do objeto da ação, mas unicamente do princípio do querer, segundo o qual a ação foi produzida, sem tomar em conta nenhum dos objetos da faculdade apetitiva ${ }^{78}$.

\footnotetext{
75 Ibid., p. 21.

76 HÖFFE, Otfried. Immanuel Kant. São Paulo: Martins Fontes, 2005, p. 193.

77 KANT, Immanuel. Fundamentação da metafisica dos costumes. Lisboa: Edições 70, 19(??), p. 57.

${ }^{78}$ KANT, Immanuel. Fundamentação da metafisica dos costumes. São Paulo: Cia. Ed. Nacional, 1964, p. 60.
} 
Dito doutra forma: o fim não justifica os meios, não basta a intenção ser boa, é preciso que a regra pela qual o ser racional pautou sua ação seja igualmente boa. O valor moral da ação reside na intenção, mas deve-se considerar, ainda, a razão pela qual determinado fim é almejado. Pascal descomplexifica esta máxima - princípio do querer: "não é o objeto que desejo atingir que faz o valor moral do meu ato, mas a razão pela qual eu quero atingi-lo. " 79 .

A partir de tais proposições - intenção e querer-, Kant define o dever como a necessidade de cumprir, realizar ou exercer uma ação por respeito à lei moral ${ }^{80}$. Isto é, a boa vontade é determinada pela representação da lei moral. Agir segundo a representação das leis é agir segundo princípios, ou seja, ter boa vontade. A ação em obediência à lei independe de seu conteúdo, e a máxima de obedecer a essa lei, inclusive com danos as minhas inclinações e tendências, decorre da característica da ação moral não retirar seu valor do fim visado. Portanto, "nada mais resta do que a conformidade universal das ações a uma lei em geral que deva servir-Ihe de princípio: noutros termos, devo portar-me sempre de modo que eu possa também querer que minha máxima se torne em lei universal." 81 .

Uma ação será moralmente boa quando o sujeito agir como se sua ação se tornasse em lei universal da natureza. Dessa forma, explana Kant que meio mais rápido e infalível de nos informar se uma ação é moralmente boa, consiste em perguntar a si mesmo: "ficaria eu satisfeito, se minha máxima (tirar-me de dificuldades por meio de uma promessa enganadora) devesse valer como lei universal (tanto para mim como para os outros? ${ }^{82 " .}$ Ademais estabelece o imperativo prático, para determinar se uma ação é moralmente boa, o homem deve "procede[r] de maneira que trates a humanidade, tanto na tua pessoa como na pessoa de todos os outros, sempre ao mesmo tempo como fim, e nunca como puro meio. ${ }^{83 \prime}$. Constituindo-se a boa vontade enquanto parâmetro da moralidade.

Essas são as regras morais aceitáveis, ou melhor, são aquelas que todos poderiam/deveriam adotar, que expressam o que se denomina dever-ser. Kant argumenta que na base de nossas posições morais há um conjunto de máximas universais e atemporais: os imperativos categóricos ${ }^{84}$. Tais máximas, mostram a relação de uma lei

79 PASCAL, Georges. O pensamento de Kant. 6. ed. Petrópolis, RJ: Vozes, 1999, p.114.

80 KANT, Immanuel. Fundamentação da metafisica dos costumes. São Paulo: Cia. Ed. Nacional, 1964.

81 Ibid., p. 62.

82 Ibid., p. 63.

83 KANT, Immanuel. Fundamentação da metafisica dos costumes. São Paulo: Cia. Ed. Nacional, 1964, p. 69.

84 "Como toda a lei prática representa uma acção possível como boa e por isso como necessária para um sujeito praticamente determinável pela razão, // todos os imperativos são fórmulas da determinação da aç̧ão que é necessária segundo o princípio de uma vontade boa de qualquer maneira. No caso de a acção ser apenas boa como meio para qualquer outra coisa, o imperativo é 
objetiva da razão para uma vontade. O imperativo categórico seria aquele que está relacionado com a moral, que regula uma questão interna, é autônomo. Representa uma ação como objetivamente necessária por si mesma, sem relação com qualquer outra finalidade. É, inclusive, tal imperativo que serve à construção de uma noção de pessoa como valor, a partir de Kant, já que, como Reale mesmo aponta

Quanto Kant dizia: - "Sê uma pessoa e respeita os demais como pessoas" -, dando ao mandamento a força de um imperativo categórico, de máxima fundamental de sua Ética, estava reconhecendo na pessoa o valor por excelência. É nesse sentido que podemos concordar com Francisco Romero, quando diz que "ser é transcender" 85 .

Em Kant, o que importa no valor moral não são as ações exteriores que visualizamos, mas os princípios internos da ação, os quais não visualizamos. A moral kantiana não pode ser tirada da experiência, uma vez que seu objeto é ideal, é o que deve ser, e não o que é. Para o filósofo "não se poderia prestar pior serviço à moralidade, do que fazê-la derivar de exemplos" ${ }^{86}$; não poderíamos, assim, apoiar a ideia moral na experiência.

Nesse caminhar, elucida que a base do conceito de valor moral é a dimensão apriorística do sujeito transcendental. Dessa forma, o sujeito empírico é afetado pelos impulsos sensíveis, isto é, sua ação está sempre a mercê de ser contaminada por interesses externos. Como esclarece Pascal, a manifestação da vontade pode sofrer alterações no mundo sócio-político, visto que a vontade não é indiferente ao mundo empírico e suas manifestações econômicas, sociais, espirituais, religiosas, etc ${ }^{87}$. Por conta disto, o valor moral, para Kant, não subsiste ao mundo empírico, visto que a boa vontade não se constitui enquanto parâmetro objetivo para podermos saber se alguém está agindo ou não moralmente.

hipotético; se a acção é representada como boa em si, por conseguinte como necessária numa vontade em si conforme à razão como princípio dessa vontade, então o imperativo é categórico. " KANT, Immanuel. Fundamentação da metafisica dos costumes. Lisboa: Edições 70, 19(--), p. 50.

${ }^{85}$ REALE, Miguel. Filosofia do direito. 17. ed. São Paulo: Saraiva, 1996, p. 217.

${ }^{86}$ KANT, Immanuel. Fundamentação da metafísica dos costumes. São Paulo: Cia. Ed. Nacional, 1964, p. 69.

87 PASCAL, Georges. O pensamento de Kant. 6. ed. Petrópolis, RJ: Vozes, 1999. 


\subsection{Husserl: intencionalidade da consciência e fenomenologia das essências}

Como já demonstrado nesse trabalho, Miguel Reale, para sustentar sua noção de valor preconizada em sua teoria tridimensional do Direito, utiliza-se da categoria da intencionalidade que extrai da fenomenologia husserleana, de modo a dar as bases de seu historicismo axiológico. É, pois, necessário um olhar mais atento sobre tal categoria, de modo a percebermos as influências da fenomenologia pura de Husserl na construção teórica realeana.

A construção da fenomenologia husserleana conforma duas principais influências teóricas que devem ser destacadas: a filosofia de Franz Brentano e a de René Descartes inclusive do idealismo kantiano ${ }^{88}$. O seu filosofar opõe-se ao psicologismo, que expressa a doutrina de que "[...] a lógica é uma técnica do pensamento correto e que as leis lógicas são leis reais de nosso pensar, obtidas através de análises empírico-psicológicas" ${ }^{89}$, pois afirma que toda técnica deve ser vista como caso particular de uma disciplina normativa, já que para que se possa investigar o pensar correto se faz necessário, de primeira, estabelecer as normas fundamentais segundo as quais devem ser julgados os objetivos ${ }^{90}$.

É sabido que Husserl, o tido pai da fenomenologia, tenta distanciar-se de uma metafísica, em seu sentido tradicional, de modo a propor um voltar-se sobre as coisas mesmas, a partir do que chama redução fenomenológica (ou epochè). Mediante o método husserleano, seria possível pôr o juízo, de modo intencional, em suspensão, isto é, colocálo entre parênteses, permitindo-se ao sujeito uma abertura fenomenológica para quem ele mesmo é. Dito de outro modo, com o isolamento dos veres prévios atinentes ao sujeito, possibilitar-se-ia o seu elevar-se ao que chamou Husserl de consciência pura - resíduo fenomenológico. No método de pôr entre parênteses, diversos componentes se distinguem. São eles: a) redução entre parênteses histórica, na qual "é deixado de lado tudo o que recebemos em relação a teorias e opiniões [...]. Apenas a coisa imediatamente dada deve falar ${ }^{91}$; b) colocação entre parênteses existencial, a partir do que deverá se dar "a abstração de todos os juízos de existência, mesmo daqueles nos quais existe uma evidência

\footnotetext{
${ }^{88}$ A esse respeito vide STEGMÜLLER, Wolfgang. Filosofia Contemporânea: Introdução Crítica (Hauptströmmungen der Gegenwartsphilosophie: eine kritische Einführung). São Paulo, Universidade de São Paulo, 1977, p. 58.

89 lbid., p. 58.

90 lbid., p. 58 - 59. Não nos ateremos ao mérito dessa questão, pois tal verticalização cognoscitiva totalizaria um trabalho científico individualizado.

${ }^{91}$ STEGMÜLLER, Wolfgang. Filosofia Contemporânea: Introdução Crítica (Hauptströmmungen der Gegenwartsphilosophie: eine kritische Einführung). São Paulo, Universidade de São Paulo, 1977, p. 74.

Revista Publicum

Rio de Janeiro, v.2, n. 2, 2016, p. 169-204

http://www.e-publicacoes.uerj.br/index.php/publicum

DOI: $10.12957 /$ publicum.2016.22557
} 
absoluta" 92; c) redução eidética, no que se realizará a passagem espiritual do fático para a essência, e d) redução transcendental, "através da qual os dados da consciência ingênua tornam-se fenômenos transcendentais da 'consciência pura'” 93 . Na interpretação de Reale:

Sustenta Husserl que podemos intuir os fenômenos de forma puramente intelectual, sem ser necessário - do ponto de vista lógico, e não do ponto de vista genético-psicológico -, recorrer a confrontos ou a comparações entre dois ou mais seres, como acontece na aplicação do método indutivo. A intuição coloca-nos diante de um único fenômeno, que devemos analisar $\mathrm{cm}$ sua imediata presencialidade, visando a atingir ao seu "eidos" ou essência, com todo o rigor exigido pelo saber filosófico, ou, como frisa Husserl, segundo fases "dotadas de evidência apodítica" 94.

Desse modo, o que Husserl parece pretender é um método que traga à tona as essências em si, a partir de uma investigação que se funda na intencionalidade da consciência. A partir da abstração do mundo da vida, então, seria possível ao sujeito elevarse ao seu eu residual, fundado na subjetividade transcendental e cindido do mundo histórico. Nessa tarefa, faz-se imperioso o afastamento do sujeito de seus preconceitos ou pré-juízos referentes aos fenômenos, de maneira a poder se colocar num estado de disponibilidade em face do objeto, captando assim a sua pureza e integralidade, recebendoo tal como se oferece originariamente na intuição ${ }^{95}$. Mas, a descrição feita pelo sujeito do objeto que se coloca em toda a sua essencialidade deve ser feita de maneira neutra e que se processe através de uma sucessão de perguntas em sentido contrário ao experiencial, isto é, ao que é atinente ao vivido, "[...] que vão como que desdobrando o objeto em suas camadas ou estruturas, elevando-se de uma intuição empírica à intuição da essência, desprezando o puramente fático e particular" ${ }^{96}$. Como aponta Reale:

Através desta análise em progressão, podemos e devemos atingir uma ou várias notas que não poderemos mais colocar entre parêntesis, porque, se o fizermos, o próprio objeto acabará entre parêntesis...

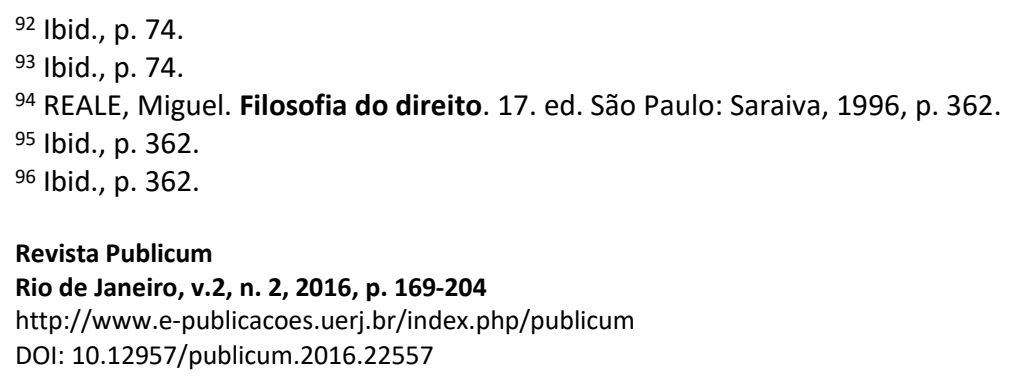


Quando atingimos esse ponto, esse dado não abstraivel, temos o que se denomina o eidos, a essência da coisa (redução eidética) ${ }^{97}$.

No entanto, deve-se ter por certo, como Reale mesmo destaca, a relevante distinção entre a fenomenologia das essências de Husserl e a doutrina a priori transcendental de Kant, já que o eu puro a que se reduz o sujeito na investigação fenomenológica não se reduz ao eu puro universal e formal próprio da filosofia de Kant, mas se fundamenta na temporalidade e historicidade, de modo que o a priori material não mais depende do sujeito cognoscente, mas se deduz das coisas mesmas e a tais é inerente ${ }^{98}$.

Como já se referiu acima, são conhecidas as influências de Brentano no filosofar husserleano. É, inclusive, a partir da teoria brentaniana da intencionalidade que Husserl irá formular sua fenomenologia da consciência ${ }^{99}$. A seu turno, a noção de intencionalidade empunhada por Husserl parece chegar a um status próprio, já que essencialmente se distingue da doutrina brentaniana por admitir sensações reais carentes de intencionalidade, que são apreendidas através dos atos intencionais dirigidos ao objeto e, ao mesmo tempo, animadas por ele ${ }^{100}$. Assim, como destaca Stegmüller:

[...] a mesma coisa que, em relação ao objeto, forma uma representação intencional, em relação à sensação é uma apreensão, interpretação a apercepção objetiva. As sensações são vividas, mas não aparecem objetivadamente, isto é, não são percebidas. ${ }^{101}$

No que tange à estrutura dos atos intencionais, distingue o autor entre três significações de consciência, a saber: a) consciência como entrelaçamento das vivências psíquicas empiricamente verificáveis numa unidade de vivência; b) consciência como percepção interna das próprias experiências, e c) consciência como designação que resume todos os atos psíquicos ou vivências intencionais - noção de que se vale para sua construção teorética ${ }^{102}$.

\subsection{Reale: dos limites da pretensão sintetizante}

${ }_{97}$ REALE, Miguel. Filosofia do direito. 17. ed. São Paulo: Saraiva, 1996, p. 362.

98 Ibid., p. 362.

99 STEGMÜLLER, Wolfgang. Filosofia Contemporânea: Introdução Crítica (Hauptströmmungen der Gegenwartsphilosophie: eine kritische Einführung). São Paulo, Universidade de São Paulo, 1977, p. 66. 100 Ibid., p. 68.

101 Ibid., p. 68-9.

102 Ibid., p. 68. 
Duas são as perspectivas fundamentais que podem ser extraídas a partir de uma incursão na teoria do valor realeana que se pretenda crítica, a saber: a) os valores expressam a síntese a priori do que é o ser mesmo do homem e, desse modo, possibilitam a correlação sujeito-objeto, na perspectiva ontognoseológica, enquanto mediadores da relação eumundo, e que b) tais valores, mediante a intencionalidade da consciência, são objetivados e transformados em cultura no decorrer dos processos históricos, podendo, inclusive, alçar à posição permanente e cristalizada de invariantes, o que denuncia sua tradição ontoteológica. É a conclusão a que nos leva, em suas palavras:

Meditando sobre a natureza do homem, cuja problemática veio aos poucos dando colorido antropológico à Filosofia de nosso tempo, cheguei a algumas conclusões que se correlacionam no âmago de seus enunciados, a partir da consideração do homem mesmo como valorfonte de todos os valores. Nessa linha de pensamento, que se abebera nas mais puras fontes da tradição cristã, creio que o ser do homem é o seu dever ser e que, por isso, é da essência do valor a sua realizabilidade. Se assim é, cumpre também reconhecer que o campo da realização dos valores - os quais seriam simples quimeras se jamais pudessem se converter em momentos da experiência humana - é representado pela História. Aliás, se o ser do homem é seu dever ser, o ser do homem é essencialmente histórico. ${ }^{103}$

Em sua palestra intitulada 'Invariantes Axiológicas', Reale nos dá a seguinte informação que a tais perspectivas podemos relacionar:

Penso, contudo, que entre a concepção idealista da experiência axiológica como totalidade do processo histórico da ldéia ou do Absoluto, e a vertente oposta, a visão empírica do historicismo relativista, é possível uma terceira posição, que resulta de uma compreensão transcendental (em sentido em que Kant e Husserl empregam este adjetivo, bem diverso do vigente na Metafísica tomista) do valor em correlação com a experiência histórica [sic] $]^{104}$.

103 REALE, Miguel. Invariantes axiológicas . Estudos Avançados, São Paulo, v. 5, n. 13, p. 131-144 , dec. 1991. ISSN 1806-9592. Disponível em: <http://www.revistas.usp.br/eav/article/view/8625>. Acesso em: 25 feb. 2016. doi:http://dx.doi.org/10.1590/S0103-40141991000300008.

${ }^{104}$ Ibid.

Revista Publicum

Rio de Janeiro, v.2, n. 2, 2016, p. 169-204

http://www.e-publicacoes.uerj.br/index.php/publicum

DOI: 10.12957/publicum.2016.22557 
Como o enunciado acima nos sugere, é na compreensão transcendental do valor que se conformam, na ótica realeana, personalismo e historicismo axiológico. Então, cabe aqui entender de que modo se pode admitir uma noção de valor que alce ao status de fundamental e transcendental, no sentido kantiano-husserleano do termo, ao tempo que seja histórica. Isto parece-nos forçoso, prima facie, já que ao admitirmos a historicidade do valor estaríamos a dizê-lo como circunstância, como tempo ${ }^{105}$, como mutabilidade, o que negaria seu caráter permanente. A seu turno, ao cristalizarmos a noção de valor como transcendência, como a priori e já-aí ante a experiência, deveríamos necessariamente negar o seu caráter de tempo e de história. Trata-se, portanto, de ponto nevrálgico da teoria dos valores realeana.

Como se teve a oportunidade de perceber, a partir do caminho percorrido sobre o desenvolvimento da teoria realeana do valor e de suas bases teoréticas, parece-nos que a construção axiológica de Miguel Reale não alça à posição superadora por ele pretendida das doutrinas kantiana e husserleana.

Reale se utiliza do valor como elemento de mediação entre o sujeito e o mundo, atuando como fator possibilitador da correlação entre tais categorias metafísicas, e como cultura que se objetiva no decorrer dos processos de objetivação das intencionalidades na história, de modo a poder assumir um caráter de fundamento absoluto, como que se fossem categorias inatas, já, de algum modo, dadas num plano a priori. Nesse ponto, ele habita a tradição kantiana de sua razão pura no que se refere à sustentação dos juízos sintéticos a priori, e sua razão prática, ao tratar de valores que se assumem e se exteriorizam como absolutos e universais numa dada conjuntura social e histórica.

Ao assinalar que os valores se exteriorizam mediante a objetivação das intencionalidades da consciência, Reale vale-se da noção husserleana de cogito, de maneira a veicular a problemática histórica que Husserl traz ao cenário filosófico em seus escritos fenomenológicos. No entanto, ressalte-se que essa postura realeana de síntese apressa uma resposta pretensiosamente conclusa, o que nos parece forçoso se considerarmos a tradição fenomenológica a que se filia, além de tentar unir o pensamento histórico e circunstancial à noção de valor enquanto invariante.

Fica-nos a impressão de que tal movimento de superação não se efetiva na plenitude da eloquência com que Reale advoga superar o idealismo alemão, já que parece que

105 Aqui, tempo é empregado no sentido de existência, de vivência, de historicidade, portanto, como em Heidegger, ver HEIDEGGER, Martin. Ser e tempo. Partes I e II, tradução de Marcia Sá Cavalcante Schuback. Petrópolis: Vozes, 2002.

Revista Publicum

Rio de Janeiro, v.2, n. 2, 2016, p. 169-204

http://www.e-publicacoes.uerj.br/index.php/publicum

DOI: 10.12957/publicum.2016.22557 
permanece no lugar comum desse modo de pensar, e sustenta uma realidade fora do vivido e da existência do ser-no-mundo presente no sujeito como fundamento último de sua existência, em sua celebre frase "o ser do homem é o seu dever ser".

Assim, em sua construção teórica, Reale parece não levar em conta o aspecto idealista que caracteriza tanto a filosofia de Kant quanto a de Husserl, ou, se leva em conta, sua pretensão de superação de tais e a formação de sua noção de valor desvinculada do rol de objetos ideais não logra êxito, já que ao desembocar quase que num inatismo kantiano ou numa subjetividade pura husserleana parece negar ou relativizar demais o pensamento histórico. Isto porque, afirma o valor como categoria quase que inata e que pode se petrificar com status de fundamental, mediante os processos históricos de objetivação das intencionalidades da consciência.

Desse modo, a tentativa de superação das doutrinas kantiana e husserleana, a partir da dialética de complementaridade que se deduz da correlação ontognoseológica entre sujeito-objeto, parece não ser suficiente para superar ou para unir o pensamento historicista ao personalista no tocante à axiologia, posto que se centra na pretensão idealista em negar a temporalidade em face de categorias fundamentais ou inatas, seja fora do mundo da vida, seja nele petrificadas.

\section{Considerações Finais}

$\mathrm{Na}$ esteira de ideias apresentada, a interpretação fenomenológica que fazemos, ao modo crítico, da construção teórica axiológica realeana não é outra senão a de que o seu projeto se afigura inconsistente, inclusive para fundamentar o que denomina invariantes axiológicas, pelo menos nos moldes por ele apontados, que se fundam na pretensa união entre historicismo e jusnaturalismo transcendental. Aqui, é interessante evidenciar que não tomamos partido desta ou daquela doutrina para nos lançarmos em nosso projeto, pelo menos, prima facie, já que apontamos uma contradição imanente ao pensamento de Reale, da qual, apesar de tentar, parece-nos, não consegue fugir o autor.

Pensar o problema dos fundamentos do Direito sem recair num idealismo é, sem dúvida, para nós uma questão. Tal questão teve como porta de entrada para o claro do desocultamento a incursão na teoria dos valores realena, de modo a nos implicarmos na questão, na trilha que percorremos, já que não nos afigura adequado, e possível, pensar determinado problema desvinculado da tradição. Foi a eleição que fizemos.

Aqui, também interessa ratificar nossas bases epistemológicas, as quais se fundam na atitude fenomenológico-hermenêutica, tendo em vista a perspectiva de que o ser 
humano não é objeto e suas atividades não são meras reações. O homem é visto como atribuidor de significados históricos; o mundo e a realidade não são objetivos exteriores ao homem, mas socialmente construídos e recebem um significado a partir do homem; a experiência vivida é em si mesma um processo interpretativo-compreensivo. Dessa forma, o que aqui pretendíamos não era desvelar o fenômeno em sua totalidade, mas pelo fenômeno desentranhar uma das possibilidades de des-ocultamento daquilo que é.

\section{Referências}

ARENDT, Hannah. O interesse pela política no pensamento europeu recente. Disponível em: http://uww.oquenosfazpensar.com/adm/uploads/artigo/o_interesse_pela_politica_no_pensamento_filosofico_eur opeu_recente/n3hannah.pdf $>$.Acessoem:24fev. 2016.

ARISTÓTELES. Metafísica. São Paulo: Edições Loyola, 2002.

BITTAR, Eduardo. Metodologia da pesquisa jurídica: teoria e prática da monografia para os cursos de direito. 4. ed. São Paulo: Saraiva, 2005

CHAUI, M. Convite a filosofia. 10.ed. São Paulo: Atica, 2000.

COELHO, Luiz Fernando. Crítica do direito e criticismo ontognoseológico (em homenagem a Miguel Reale).Seqüência: Estudos Jurídicos e Políticos. Florianópolis, p. 120-132,jan. 1981. ISSN 2177-7055. Disponível em: <https://periodicos.ufsc.br/index.php/sequencia/article/view/17238>. Acesso em: 23 fev. 2016 .

FEYERABEND, Paul. Contra o método. [S.I.] Relógio D'Água; Ciência, 2007.

GADAMER, Hans-Georg. Verdade e método I. 5. ed. Petrópolis: Vozes, 2003.

GHIRALDELLI JÚNIOR, P. A Aventura da Filosofia: de Parmênides a Nietzche. São Paulo: Manole, 2010.

GONZALEZ, Everaldo Tadeu Quilici. A Teoria Tridimensional do Direito de Miguel Reale e o novo Código Civil Brasileiro. Unimesp, 2000. Disponível em: 
<http://www.unimep.br/phpg/mostraacademica/anais/4mostra/pdfs?145.pdf>. Acesso em: 23 mar. 2016.

HEIDEGGER, Martin. Ensaios e conferências. 8. ed. Petrópolis: Vozes; Bragança Paulista: Editora Universitária São Francisco, 2012.

. Ser e tempo. Partes I e II, tradução de Marcia Sá Cavalcante Schuback. Petrópolis: Vozes, 2002.

HUME, David. Tratado da natureza humana. (Tradução de Déborah Danowski). São Paulo: Editora UNESP; Imprensa Oficial do Estado, 2001.

HUSSERL, Edmund. A crise da humanidade européia e a fenomenologia transcendental. Porto Alegre: EDIPUCRS, 2002.

. Meditações cartesianas: introdução à fenomenologia. São Paulo: Madras, 2001.

KANT, I. Prolegómenos a toda a metafísica futura: que queira apresentar-se como ciência. Lisboa: Edições 70.

. Critica da razão prática. Rio de Janeiro: Martins Fontes, 1984.

. Crítica da razão pura. São Paulo: Abril Cultural, 1980.

. Fundamentação da metafisica dos costumes. Lisboa: Edições 70, (19- -).

. Fundamentação da metafisica dos costumes. São Paulo: Cia. Ed. Nacional, 1964.

OLSON, R. Introdução ao existencialismo. São Paulo: Editora Brasiliense, 1970.

REALE, Miguel. Invariantes axiológicas . Estudos Avançados, São Paulo, v. 5, n. 13, p. 131-144 , dec. 1991. ISSN 1806-9592. Disponível em: <http://www.revistas.usp.br/eav/article/view/8625>. Acesso em: 25 feb. 2016. doi:http://dx.doi.org/10.1590/S0103-40141991000300008. . Filosofia do direito. 17. ed. São Paulo: Saraiva, 1996. 
Fundamentos da concepção tridimensional do direito. Revista da Faculdade de Direito, Universidade de São Paulo 56.2 (1961): 66-87.

. Introdução à filosofia. 4. ed São Paulo: Saraiva, 2002.

. O direito como experiência: introdução à epistemologia jurídica. 2. ed. São Paulo:

Saraiva, 1992.

Teoria tridimensional do direito. 5. ed. rev. e reestruturada. São Paulo: Saraiva, 1994.

SCHELER, Max. Ética: nuevo ensayo de fundamentación de un personalismo ético. Traducción de Hilario Rodríguez Sanz. Madrid: Caparrós Editores, 2001. (Colección Esprit).

SEIBT, Cezar. Elementos da crítica do jovem Heidegger a Kant e Husserl. Acta Scientiarum. Human and Social Sciences. 2011. Disponívelem: 〈http://wnww.redalyc.org/articulo.oa?id=307325341004>. Acesso em:23fev. 2016.

STEGMÜLLER, Wolfgang. Filosofia Contemporânea: Introdução Crítica (Hauptströmmungen der Gegenwartsphilosophie: eine kritische Einführung). São Paulo, Universidade de São Paulo, 1977, p. 58.

STRAWSON, P. Análise e metafísica: uma introdução à filosofia. São Paulo: Discurso Editorial, 1992.

WARAT, Luiz Roberto. A pureza do poder: uma análise crítica da teoria jurídica. Florianópolis: Ed. Da UFSC, 1983.

PONTES DE MIRANDA. Sistema de Ciência Positiva do Direito. 2ª ed. Rio de Janeiro: Editor Borsoi, 1972. Tomo I.

Recebido em 20/04/2016

Aceito em 27/12/2016 